\title{
European Real Exchange Rates after Bretton Woods: A Re-examination
}

\author{
Serge Rey \\ University of Pau et Pays de l'Adour \\ Pascal Varachaud \\ University of Pau et Pays de l'Adour
}

\begin{abstract}
This paper examines the hypothesis of Purchasing Power Parity (PPP), i.e. the proposition that the equilibrium real exchange rate is a constant in the long run, in the case of Europe of the 15. For that purpose, we study the statistical properties of 14 European bilateral real exchange rates against the Deutschmark, over the period 1973-1998. These rates are constructed using consumer prices (CPI), wholesale prices (WPI) and unit labor costs (ULC). The results of various unit-root tests show that globally there is little evidence to support PPP, $i$. e. the stationarity hypothesis of real exchange rates is rejected. At the most, some meanreverting process are verified; in two cases with CPI, seven cases with WPI and three cases with ULC. Furthermore, general PPP with consumer prices is verified in only one case, namely between France and Germany. Finally, the evidence on bilateral real exchange rates suggests that inference on PPP is not sensitive to whether the country is a member of an European exchange system (snake and/or EMS). There is no systematic influence of exchange rate regimes.
\end{abstract}

- JEL-Classification: C22, F15, F31

- Key Words: Real Exchange Rate, PPP, EMS, Unit Roots, Long Memory, Mean-reversion, Structural Breaks.

\footnotetext{
*Corresponding address: Serge REY, Department of Economics, C A.T.T, University of Pau et Pays de l'Adour. Avenue du Doyen Poplawski, BP 1633, 64016 Pau Cedex, France. E-mail: Serge.rey@univ-pau.fr; Pascal Varachaud, Department of Mathematics, University of Pau et Pays de l'Adour (C)2002-Center for International Economics, Sejong Institution, All Rights Reserved.
} 


\section{Introduction}

Since the breakdown of the Bretton Woods system, many works have been dedicated to the study of exchange rates. On the one hand, the theoretical literature has been interested by the exchange rates models: Purchasing Power Parity (PPP), monetary model, portfolio model, $\ldots{ }^{1}$ On the other hand, the empirical literature has examined the links between exchange rates and relative prices, differential interest rates, money aggregates, outputs... The poor predictive power of these models (see Meese and Rogoff 1983, 1988) brought many authors to reconsider statistical properties of the exchange rates. These empirical researches followed the development of econometric methods, especially unit-root tests. An important question was whether exchange rates behave as a random walk or not. Among these studies, many concern the behavior of the real exchange rates, defined as the nominal exchange rate deflated by a ratio of domestic to foreign price levels. According to the standard PPP theory developed by the Classics and Cassel (1916, 1923), in the long run the nominal exchange rate must revert to this PPP rate.

If Cassel's proposition is true ${ }^{2}$, the real exchange rate has to be stationary or in other words, the nominal exchange rate and the price levels are cointegrated. In this case, exogenous shocks have a transitory effect on the real exchange rate and the changes in the rate ( deviations from PPP) are serially correlated. Conversely, if we are unable to detect serial correlation, this is evidence in favor of ex-ante PPP (Adler and Lehmann 1983), and evidence against traditional PPP since no mean reversion can be identified. In this case, exogenous shocks have a permanent effect.

The empirical studies lead to many controversies, insofar as many conclude in favor of PPP, and as many reject it (Whitt 1992). In order to explain these divergences, some emphasize the exchange regimes (Diebold, Husted et Rush 1991), or the importance of «the evolution of economic institutions, market structure, and monetary and fiscal policy » (Grili and Kaminsky 1991). For others, the inflationist situation plays a determining role (Bleaney, Leybourne and Mizen 1999). Finally, we may question the aptness of econometric tests. Thus for instance, Abuaf and Jorion (1990 p.172) conclude: « To date, most empirical tests of Purchasing Power Parity have been unable to reject the hypothesis that the real exchange rate follows a random walk. In our opinion, these results reflect the poor

${ }^{1}$ See for example DORNBUSCH (1989).

${ }^{2}$ See BALASSA (1964), SAMUELSON (1964), OFFICER (1976) for criticisms of the proposition. 
power of the tests employed rather than evidence against PPP».

These seemingly conflicting results raise a problem for both theoreticians and policymakers. Theoreticians have needed PPP in order to close their models (monetary model for instance), while the policymakers can use PPP as a guideline for their policy (Hakkio 1992). PPP can be a good referent, in particular, for parity adjustments in a fixed exchange rate regime. Many economists (see Eichengreen, 1993; Chueng and al., 1995) argue that within the European Monetary System (EMS), realignments were managed in order to eliminate inflation differentials (or costs differentials?), or in the same way to maintain relative competitiveness.

For these reasons, our purpose in this paper is to test the hypothesis of PPP by investigating the behavior of European real exchange rates (the 15 current member countries) over the period 1973-1998, using Germany as the benchmark country. This paper has two goals.

Firstly, at an economic level, understanding the behavior of real exchange rates may answer some important questions which divide economists:

- Is PPP better verified in a fixed exchange rate system or in a flexible regime? The period under investigation is characterized by two exchange rate regimes: the «snake» from 1972 to 1978 and the European Monetary System (EMS) from 1979 to 1998. Insofar as all European currencies were not together in these systems during the whole period, we have a good panel of research for comparing the real exchange rates according to the degree of exchange rates flexibility. This point is very important, because the stationarity of the real exchange rate is synonymous with real integration of European economies, whereas the nonstationarity of these rates rather means that financial integration dominates (hypothesis of efficient market, Roll 1979, Adler and Lehmann 1983, Mac Donald 1985a,b, 1995). Thus, we may conclude on the economic integration level of the European countries before the adoption of the Euro.

- What is the best definition of PPP ? Here, we consider three: one is based on price levels measured by consumer price indices (CPI); another one on wholesale price indices (WPI), and the last one on unit labor costs (ULC). Thus, we may test a broad definition of PPP (with CPI) which includes nontradable goods and tradable goods prices; a more restricted definition with only tradable goods prices (with WPI) and finally a cost parity (with ULC of the manufacturing sector).

Secondly, at the empirical level, the aim is to study the statistical properties of the real exchange rates. If PPP is verified, the real exchange rates are stationary. Also, the shocks on these rates (economic policy change, devaluation ...) will 
have transitory effects, and these rates will have a tendency to revert to their equilibrium value. The equilibrium real exchange rate will be a constant. In this case, the real exchange rates cannot be cointegrated with other macroeconomic variables, such as gross national product, interest rates, trade flows ...

In order to analyze these properties, we use unit-root tests. Some standard tests permit to test the null hypothesis of a random walk (Dickey and Fuller, Phillips and Perron ...), while others test the null hypothesis of stationarity (Kwiatkowski and al.). But we know that these tests may be biased (non rejection of the unit-root hypothesis; evidence against PPP), especially in two cases: when there are shifts in the intercept and/or slope in the trend function of stationary time series (Perron); when the order of integration of the real exchange rate is fractional rather than integer. New tests were developed to take into account these problems. So, we choose to use these different tests in order to reduce mistakes in interpretation.

The paper is organized as follows. Section 2 presents a brief discussion of European exchange rate regimes and charts of the real exchange rates. Empirical estimates of conventional unit-root tests are analyzed in section 3. In section 4, we present unit-root tests modified for structural breaks. The results of fractional integration tests are discussed in section 5. Finally, in section 6 we summarize our findings.

\section{History of European Real Exchange Rates}

\section{A. Exchange Rate Regimes}

After the collapse of the Bretton Woods System, two exchange rate regimes were tried in Europe: the «snake» regime and the European Monetary System (EMS).

«Snake» period, April 1972 to December 1978

When European currencies began to float freely against the dollar in March 1973, « snake » arrangements had been working since April 1972. Exchange rate fluctuations were reduced by limiting the swings in bilateral exchange rates to a 2.25 percent band $^{3}$. Participating countries were European Economic Community (EEC) members (Germany, the Netherlands, Belgium and Luxembourg, the

\footnotetext{
${ }^{3}$ At the origin, the arrangement was known as «the snake in the tunnel» because it made the participating currencies move within the band established for the dollar by the Smithsonian Agreement of December 1971.
} 
United Kingdom, Denmark, France and Italy) and two non-EEC countries, Norway and Sweden. This system never really worked except in small countries surrounding Germany. Indeed, shortly after the first oil shock, the United Kingdom ${ }^{4}$, France and Italy withdrew from the system. The differences in economic performances and economic policies were too large to warrant fixed exchange rates ${ }^{5}$. The attempts of the French Franc to come back into the system between 1976 and 1977 failed. Only the Benelux currencies and the Danish krone for EEC countries, the Norwegian and Swedish krones for non-EEC countries remained connected with the German mark. The others floated so much that we can speak of floating exchange rates for most of the European currencies. It is this situation, incompatible with the Monetary Union goal, which led to a European response, resulting in the establishment of the EMS.

\section{EMS period, March 1979 to December 1998}

Instituted on March 1979, the EMS was a system more balanced than the «snake». Participating countries in the system determined an official exchange rate for all their currencies, and a band around these central parities set at $+/-$ $2.25 \%$. The members of the European Community, except for the United Kingdom, agreed to start the scheme in 1979.

Other currencies joined later: the Spanish Peseta in June 1989, the pound Sterling in October 1990, the Portuguese Escudo in April 1992, the Austrian Shilling in January 1995, the Finnish Markka in October 1996 and finally the Greek Drachma in march 1998. As for the Swedish Krone, it never joined in the EMS.

During these twenty years, we can distinguish three stages :

- From 1979 to 1987, the realignments were very frequent. For example, we had four devaluations of the French Franc vis à vis to the Deutschemark: three between 1981 and 1983, and the fourth in 1986.

- From 1987 to 1992, no realignment took place.

- From 1992 to 1998, there was a new instability period with two exchange crises, in September 1992 and August 1993. It is during this phase that the Sterling and the Italian Lira dropped out of the system. To slow down speculation, the members chose to widen the band of fluctuation to $+/-15 \%$.

${ }^{4}$ The United Kingdom joined the system from May to June 1972.

${ }_{5}^{5}$ See THYGESEN (1979) for criticisms on the conception of the « snake » arrangement.

${ }^{6}$ Italy was allowed to adopt a wide $+/-6$ percent band. 
This implied that the currencies would be able to fluctuate up to $30 \%$, «transforming the system into a quasi-floating exchange rate regime» (De Grauwe 1994)

Hence, it is not possible to say that fixed exchange rates over the whole EMS period prevailed, except for a nucleus constituted by the Deutschemark, the Dutch Guilder and the Belgian Franc.

An important question remains. Did the frequent realignments result in a stabilization of the real exchange rates? A first answer may be given by an investigation of the real exchange rates dynamics.

\section{B. Real Exchange Rates}

In the EMS, the Deutschmark played a central role. Therefore, we will choose this currency as the pivot to calculate the various bilateral real exchange rates. If $E_{a l l / i}$ represents the nominal exchange rate, that is the amount of Deutschmarks for one unit of domestic currency $i$, the absolute PPP rate between the country i and Germany is:

$$
P P A_{t, a l l / i}=\frac{P_{i}^{a l l}}{P_{t}^{i}}
$$

where $P_{t}^{i}$ and $P_{i}^{\text {all }}$ are the price levels in the country $i$ and in Germany $(A l l)$. The real exchange rate vis à vis Germany, for any period $t$, is:

$$
P P A_{t, \text { all } / i}=\frac{E_{t, \text { all } / i}}{P P A_{t, \text { all } / i}}=\frac{E_{t, \text { all } / i} \cdot P_{t}^{i}}{P_{i}^{\text {all }}}
$$

A rise (resp. a fall) in $E R$ is synonymous with a real appreciation (resp. depreciation) of currency $i$ against the Deutschmark. In practice, we use two price indexes (consumer prices and wholesale prices) and a unit labor cost index as quarterly data, for the construction of real exchange rate index ${ }^{7}$. We retain 1973I-1978-IV as base period ${ }^{8}$.

In Charts 1-2, we present plots of bilateral real exchange rates. Note that:

\footnotetext{
${ }^{7} \mathrm{We}$ also calculate a nominal exchange rate index with the same base period. For the study of the statistical properties, this base period is not important. But, if we consider that 1973.I1978.IV is an equilibrium period for the exchange rate, we can interpret as undervaluation (resp. overvaluation) a value of the real exchange rate smaller (resp. greater) than one. ${ }^{8}$ The data were extracted from the IMF International Financial Statistics CD-Rom and from Eurostatistics. The unit labor costs are defined as the wage deflated by labor productivity (ratio of manufacturing production to number of manufacturing employees).
} 
- The dynamics of real rates for some countries differs according to the price index. There are divergences between the relative consumer prices (as proxies for general price level) and the relative wholesale prices (as proxies for tradable goods prices). It is the case for the French Franc, the Belgian Franc, the Spanish Peseta, the Austrian Shilling, the Irish Punt and the Danish Krone.

- The real rates calculated with unit labor costs very often have marked trends. For the French Franc, the Belgian Franc, the Dutch Guilder, the Austrian Shilling, the Finnish Markka, the Irish Punt, and the Swedish Krone, we observe a strong real depreciation over the period.

This situation can be interpreted as a tendency to undervaluation of these currencies against the German Mark (or overvaluation of the Mark), if we refer to a cost parity.

These charts seem to suggest that there is no unique model able to describe all the real exchange rates of the European currencies against the German Mark. The next sections of this paper examine the statistical properties of these rates.

\section{Conventional Unit Root Tests in Real Exchange Rates}

We will test the presence of a unit root in real exchange rates expressed in levels, or more precisely in natural logarithms. For the period $t$, these rate will be noted $r_{t}$, that is $r_{t}=\log \left(E R_{t}\right)$.

\section{A. Reference Model}

Box and Jenkins (1976) introduced a forecasting method for univariate series that is based on the notion of the ARIMA process. Applied to the real exchange rate $r_{t}$, an ARIMA $(p, d, q)$ model is defined by

$$
\Phi(B)(I-B)^{d} r_{t}=\Theta(B) \varepsilon_{t}, \varepsilon_{t} \sim\left(0, \sigma^{2}\right)
$$

with $\Phi(B)=I-\phi_{1} B-\ldots-\phi_{p} B^{p}, \Theta(B)=I+\theta_{1} B+\ldots+\theta_{p} B^{q}$ the roots of $\Phi$ and $\Theta$ are outside the unit circle and $d$ is an integer (typically 0 or 1) representing the order of integration. The modeling of time series is done generally according to an iterative process containing three stages: identification of the plausible values of $(p, d, q)$, estimation of the parameters, validation of the selected model(s) by means of statistical tests to verify the compatibility of the results with the hypothesis. A choice a posteriori may be necessary if several models are possible; then one chooses the one that supplies the greatest quantity of information (AIC or 
Figure 1.
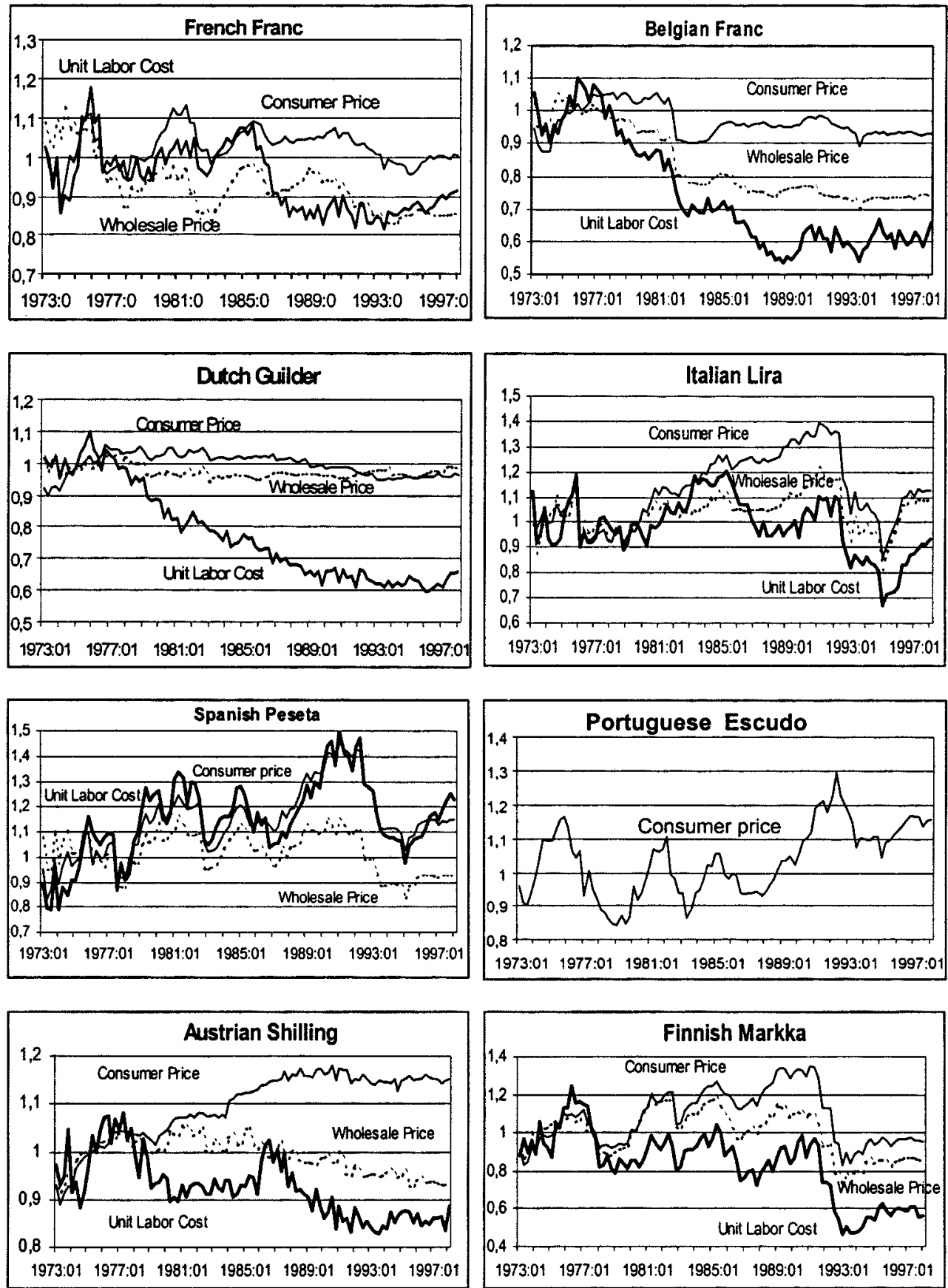

BIC criterions). Before the 1970s, the most popular method to deal with nonstationary time series was the use of stochastic models incorporating 
Figure 2.
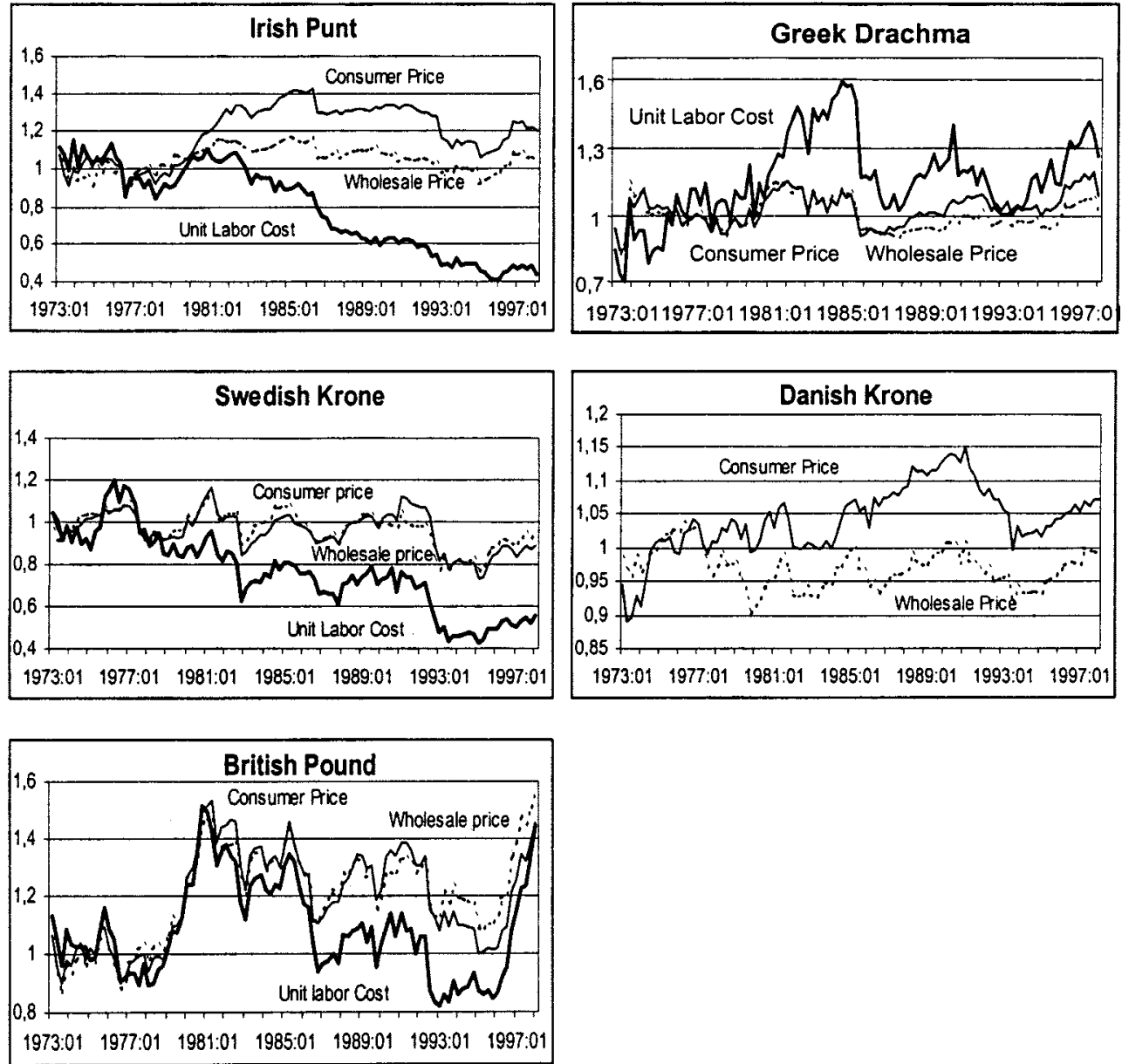

determinist trends. Time series are decomposed into two terms, the first one for deterministic tendency, the second term being purely stochastic. For example, we have:

$$
r_{t}=a t+b+\gamma(B) \varepsilon_{t}, \varepsilon_{t} \sim\left(0, \sigma^{2}\right)
$$

with $a$ and $b$ real numbers and $\gamma(B) \varepsilon_{t}$ a stationary process. The selection between these models led naturally to the unit-root tests.

\section{B. Method}

We first proceed to a short recall of the steps followed in order to highlight the presence of unit-roots in the European real exchange rates.

The unit-root tests 
Testing for the presence of a unit-root in a time series became the starting point of many works in applied economics. There is an important literature in this domain and the increasing number of unit-root tests is such that even the specialists can be disturbed, while the non-initiated will be easily discouraged. A large part of empirical works still makes use of the same simplest testing procedures, because it is unclear from the literature which test can be superior. So we choose to present and to operate several statistical approaches to specify the best behavior of real exchange rates.

Among the class of statistics generally used, Augmented Dickey Fuller tests (ADF) and Phillips Perron (PP) tests are certainly most commonly applied and are implemented on many software packages. We will not return in detail on the way these tests are built but one can refer to Dickey and Fuller (1979-1981), Said and Dickey (1984) for parametric ADF tests and Phillips (1987) Phillips and Perron (1988) for semi parametric PP tests9.

Numerous studies by simulations (Schwert, 1989; Diebold and Rudebush, 1989 ...) showed the limits of these tests. The power of discrimination for processes with a root close to one is generally weak. For example, for series of a length of 100 with a root between 0.9 and 1, the power of these tests is lower than $30 \%$. It is also established (Perron and $\mathrm{Ng}, 1996$ ) that PP test suffers severe level distortions (null hypothesis of unit root is too often rejected) in the presence of Moving Average (MA) errors with negative parameters. Ng and Perron (1995) also studied the influence of the degree of augmentation (lags) on the behavior of ADF tests and proved that the information criteria (AIC and Schwartz) tend to select a lag too weak in the presence of MA errors. So ADF and PP tests are particularly sensitive to MA errors but there is no means to discover their presence except the Box and Jenkins method.

In the same way, Leybourne and Newbold (1999), in a theoretical work completed by simulations, emphasize the important differences between ADF and PP tests when series are generated by a AR (2) processes. They recommend to use the two types of tests.

Most empirical studies, including that of Nelson and Plosser (1982), conclude that numerous economic series are nonstationary and contain a unit-root. Some authors suggested that these tests, based on the null hypothesis $\left(\mathrm{H}_{0}\right)$ of unit root (and built from the least squares estimate of the first AR coefficient), reject this hypothesis only in cases of a very marked stationary behavior. Stationarity tests

\footnotetext{
${ }^{9}$ See annex 2
} 
Table 1. Unit root and stationarity tests Consumer price-1973.I-1998.I

\begin{tabular}{|c|c|c|c|c|c|c|c|c|}
\hline & \multicolumn{3}{|c|}{ Augmented Dickey-Fuller tests } & \multicolumn{3}{|c|}{ Phillips-Perron tests } & \multicolumn{2}{|c|}{$\begin{array}{c}\text { Kwiatkowski- } \\
\text { Phillips-Schmidt-Shin test }\end{array}$} \\
\hline Currencies & ADF1 & ADF2 & ADF3 & Phillips & PP1 & PP2 & KPSS1 & KPSS2 \\
\hline French Franc & $\begin{array}{c}-1.59 \\
\text { Reject } \mathbf{k}<>9\end{array}$ & $\begin{array}{c}-1.86 \\
\text { eject } \mathbf{k}<>9\end{array}$ & & $-12.95^{* *}$ & -15.88 & $*-15.92$ & $\mathrm{H}_{0}$ for $\mathrm{k}>2$ & Reject $\mathbf{H}_{0}$ \\
\hline Dutch Guilder & $-1.65^{*}$ & -1.65 & $-3.52 * *$ & -7.97 & -7.86 & -7.49 & Reject $\mathbf{H}_{0}$ & Reject $\mathbf{H}_{0}$ \\
\hline Belgian Franc & -1.37 & -2.09 & -2.87 & -5.55 & -8.95 & -11.05 & Reject $\mathbf{H}_{0}$ & $H_{0}$ pour $k>$ \\
\hline Italian Lira & -1.21 & -2.10 & -2.16 & -3.49 & -7.20 & -8.92 & Reject $\mathrm{H}_{0}$ & Reject $\mathrm{H}_{0}$ \\
\hline Spanish Peseta & -0.70 & -1.78 & -1.76 & -2.73 & -8.14 & -11.43 & Reject $\mathbf{H}_{0}$ & Reject $\mathbf{H}_{0}$ \\
\hline Portuguese Es. & $-1.68^{*}$ & -1.86 & $-3.90 * *$ & $-8.89 * *$ & -9.84 & -15.32 & Reject $\mathbf{H}_{0}$ & Reject $\mathbf{H}_{0}$ \\
\hline Austrian Sh. & 0.45 & -2.39 & -1.30 & 0.05 & -3.49 & -4.98 & Reject $\mathbf{H}_{0}$ & Reject $\mathbf{H}_{0}$ \\
\hline Finnish Mark. & $-1.81^{*}$ & -2.23 & -2.16 & $-6.82 *$ & -8.59 & -8.02 & $\mathrm{H}_{0}$ for $\mathrm{k}>3$ & Reject $\mathbf{H}_{0}$ \\
\hline Irish Punt & -0.56 & -1.71 & -1.39 & -1.11 & -4.23 & -5.27 & Reject $\mathbf{H}_{0}$ & Reject $\mathbf{H}_{0}$ \\
\hline Greek Drach. & $-2.29^{* *}$ & $-3.13^{* *}$ & $-3.53 * *$ & -19.86 & $-24.14^{*}$ & $*-28.32 * *$ & ${ }^{k} \mathrm{H}_{0}$ for $\mathrm{k}>4$ & $\mathrm{H}_{0}$ for $\mathrm{k}>2$ \\
\hline Swedish Kr. & $-2.17^{* *}$ & -2.53 & -3.06 & $-8.93^{* *}$ & $-11.63^{*}$ & -15.26 & Reject $\mathbf{H}_{0}$ & $\mathrm{H}_{0}$ for $\mathrm{k}>4$ \\
\hline Danish Kr. & -0.90 & -2.00 & -2.34 & -3.51 & -7.41 & -10.39 & Reject $\mathbf{H}_{0}$ & Reject $\mathbf{H}_{0}$ \\
\hline Sterling Pound & -0.48 & -1.98 & -2.09 & -2.12 & -7.77 & -9.80 & Reject $\mathbf{H}_{0}$ & Reject $\mathbf{H}_{0}$ \\
\hline
\end{tabular}

Table 2. Unit root and stationarity tests Wholesale price 1973.I-1998.I

\begin{tabular}{|c|c|c|c|c|c|c|c|}
\hline & \multicolumn{3}{|c|}{$\begin{array}{c}\text { Augmented } \\
\text { Dickey-Fuller tests }\end{array}$} & \multicolumn{3}{|c|}{ Phillips-Perron tests } & $\begin{array}{c}\text { Kwiatkowski-Phillips- } \\
\text { Schmidt-Shin tests }\end{array}$ \\
\hline Currencies & ADF1 & ADF2 & ADF3 & Phillips & PP1 & PP2 & $\begin{array}{ll}\text { KPSS1 } & \text { KPSS2 }\end{array}$ \\
\hline French Franc & -0.20 & $-2.88^{*}$ & $-3.16^{*}$ & -2.18 & -7.09 & $\begin{array}{l}-14.2 \\
\text { reject } \mathbf{k}<\mathbf{8 6}\end{array}$ & Reject $\mathbf{H}_{\mathbf{0}} \mathrm{H}_{0}$ for $\mathrm{k}>4$ \\
\hline Dutch Guilder & -0.86 & -2.16 & -1.93 & $-5.77^{*}$ & $-27.16 *$ & $*-31.66 * *$ & Reject $\mathbf{H}_{\mathbf{0}}$ Reject $\mathrm{H}_{0}$ \\
\hline Belgian Franc & -0.53 & -2.13 & -1.29 & 0.50 & -2.11 & -5.57 & Reject $\mathbf{H}_{\mathbf{0}}$ Reject $\mathrm{H}_{0}$ \\
\hline Italian Lira & $-2.25^{* *}$ & $-2.79 *$ & -2.89 & $-13.08^{* *}$ & -17.56 & $*-18.74 *$ & 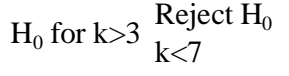 \\
\hline $\begin{array}{l}\text { Spanish Peseta } \\
\text { Portuguese Es. }\end{array}$ & $\begin{array}{l}-1.77^{*} \\
\text { Reject H } \\
\text { NA }\end{array}$ & -1.67 & -2.01 & $-16.55^{* *}$ & $-16.85^{* *}$ & $*-19.02 *$ & $\mathrm{H}_{0}$ for $\mathrm{k}>4$ Reject $\mathrm{H}_{0}$ \\
\hline Austrian Sh. & -0.03 & -0.18 & $-\mathbf{3 . 7 3} * *$ & $-6.64 *$ & -7.37 & -9.95 & Reject $\mathbf{H}_{0}$ Reject $\mathbf{H}_{0}$ \\
\hline Finnish Mark. & $-2.20 * *$ & -2.24 & -2.50 & $-6.52 *$ & -6.55 & -11.20 & Reject $\mathrm{H}_{0}$ Reject $\mathrm{H}_{0}$ \\
\hline Irish Punt & 0.17 & -1.71 & -1.70 & -0.07 & $-12.98^{*}$ & -13.64 & Reject $\mathrm{H}_{0}$ Reject $\mathrm{H}_{0}$ \\
\hline Greek Drach. & $-2.63^{* *}$ & $-2.66^{*}$ & -2.71 & $-23.74 * *$ & $-23.65 *$ & $*-23.96 * *$ & $\mathrm{H}_{0}$ for $\mathrm{k}>1 \mathrm{H}_{0}$ for $\mathrm{k}>4$ \\
\hline Swedish Kr. & $-2.39^{* *}$ & $-2.60 *$ & $-3.79 * *$ & $-9.67 * *$ & $-11.58 *$ & $-18.18 *$ & Reject $\mathbf{H}_{\mathbf{0}} \quad \mathrm{H}_{0}$ for $\mathrm{k}>4$ \\
\hline Danish Kr. & -1.52 & $-3.07 * *$ & -2.83 & $-6.63^{*}$ & $-15.11^{* *}$ & $*-15.46$ & $\mathrm{H}_{0}$ for $\mathrm{k}>1 \mathrm{H}_{0}$ for $\mathrm{k}>4$ \\
\hline Sterling Pound & 0.19 & -1.69 & -1.82 & -0.31 & -5.34 & -10.63 & Reject $\mathrm{H}_{0}$ Reject $\mathrm{H}_{0}$ \\
\hline
\end{tabular}

were proposed to deal with this problem.

\section{Stationarity Tests}

These tests, for which $\mathrm{H}_{0}$ is the hypothesis of stationarity in level or in tendency 
(against a unit root alternative), were mainly proposed by Kwiatkowski, Phillips, Schmidt and Shin (KPSS, 1992) and by Leybourne and McCabe (LMC, 1994). These tests were applied to the same series as the Nelson and Plosser study and did not reject the hypothesis of trend stationarity. While KPSS uses a non-parametric correction similar to the PP tests, LMC test takes into account additional AR delays just like ADF tests. If two tests have the same asymptotic law, LMC statistics converges a little faster than that of the KPSS statistics and seems less sensitive to the choice of the delay.

\section{Joint use of ADF, PP and KPSS Tests}

Amano and Van Norden (1992) show the efficiency of the KPSS and PP joint application. For example in the case of MA(1) errors with $\theta=0.8$, the rate of error falls from $99 \%$ for PP to $28 \%$ for KPSS and PP with series of length 100 . As soon as series exceed a length 200, the frequency of false conclusions is lower than $3 \%$. So we choose to study in conjunction the results of ADF, PP and KPSS tests. When ADF and PP tests both reject $\mathrm{H}_{0}$ in favor of the alternative of trend stationarity (see ADF3 and PP2 tests in annex 2), while KPSS accept the null hypothesis (see KPSS2 test in annex 2), then we conclude to trend stationarity. If the decisions are contradictory, we examine more complete models by investigating in detail the presence of a moving average part.

\section{Results for Unit-root and Stationarity Tests}

The results of the unit-root tests are presented in tables 1 to 3 . Table 4 gives the estimation of the real exchange rate model by the Box and Jenkins method.

For ADF and PP tests, calculations were made for several delays going from 0 to 10. Presented results concern the optimal delay calculated from the AIC criterion. For the stationarity tests, we applied two KPSS procedures ${ }^{10}$.

\section{Consumer Prices}

All the tests are concordant for six countries (Italy, Spain, Austria, Ireland, Denmark and United Kingdom) and conclude in favor of the presence of a unitroot. For all these countries, the simple random walk is the most adapted model. For Belgium, KPPS2 test does not reject the trend stationarity but the Box and Jenkins method reveals a light correlation of errors, certainly of MA(1) type. The

\footnotetext{
${ }^{10}$ We use RATS and SAS version 6 softwares for different estimations.
} 
Table 3. Unit root and stationarity tests - Unit labor costs 1973.I-1998.I

\begin{tabular}{|c|c|c|c|c|c|c|c|c|}
\hline & \multicolumn{3}{|c|}{$\begin{array}{c}\text { Augmented } \\
\text { Dickey-Fuller tests }\end{array}$} & \multicolumn{3}{|c|}{ Phillips-Perron tests } & \multicolumn{2}{|c|}{$\begin{array}{l}\text { Kwiatkowski-Phillips- } \\
\text { Schmidt-Shin tests }\end{array}$} \\
\hline Currencies & ADF1 & ADF2 & ADF3 & Phillips & PP1 & PP2 & KPSS1 & KPSS2 \\
\hline French Franc & -0.74 & -1.76 & -1.76 & $-6.44 *$ & $-13.05^{*}$ & $-23.10 * *$ & Reject $\mathrm{H}_{0}$ & Reject $\mathrm{H}_{0} \mathrm{k}$ \\
\hline Dutch Guilder & 0.09 & -2.35 & 0.29 & 0.05 & -1.67 & -16.82 & Reject $\mathrm{H}_{0}$ & Reject $\mathrm{H}_{0}$ \\
\hline Belgian Franc & 0.17 & -1.39 & -1.04 & 0.02 & -3.13 & -6.64 & Reject $\mathrm{H}_{0}$ & Reject $\mathrm{H}_{0}$ \\
\hline Italian & $-2.66 * *$ & $-2.77 *$ & -2.80 & $-13.86 * *$ & $-14.75 * *$ & -17.32 & Reject $\mathrm{H}_{0}$ & Reject $\mathrm{H}_{0}$ \\
\hline Spar & -0.82 & $-2.97 * *$ & -2.85 & -4.51 & $-11.29 *$ & -14.69 & Reject $\mathrm{H}_{0}$ & Reject $\mathrm{H}_{0}$ \\
\hline Portu & NA & & & & & & & \\
\hline Austr & -0.40 & -2.10 & $-3.48 * *$ & -3.66 & $-15.90 * *$ & $-43.18 * *$ & Reject $\mathrm{H}_{0}$ & $\mathrm{H}_{0}$ for $\mathrm{k}>2$ \\
\hline Finnis & -0.03 & -0.97 & -2.82 & -1.69 & -4.97 & -16 & Reject $\mathrm{H}_{0}$ & Reject $\mathrm{H}_{0}$ \\
\hline Irish Punt & 0.87 & -0.14 & -1.94 & 1.41 & -0.14 & -10.40 & Reject $\mathrm{H}_{0}$ & Reject $\mathrm{H}_{0}$ \\
\hline Greek Drach. & -1.09 & $-3.41 * *$ & $-3.20^{*}$ & $-6.75^{*}$ & $-14.13 * *$ & -18.04 & Reject $\mathrm{H}_{0}$ & Reject $\mathrm{H}_{0}$ \\
\hline Swedish Kr. & 0.07 & -1.51 & $-4.15^{* *}$ & -0.23 & -3.82 & $-20.39 *$ & Reject $\mathrm{H}_{0}$ & $\mathrm{H}_{0}$ for $\mathrm{k}>2$ \\
\hline Dan & NA & & & & & & & \\
\hline Sterling Pound & 0.34 & -0.56 & -2.04 & 0.87 & -0.76 & -10.47 & Reject $\mathrm{H}_{0}$ & Reject $\mathrm{H}_{0}$ \\
\hline
\end{tabular}

** and * indicate significance at 5 percent and 10 percent. $k$ for lag

Table 4. Box et Jenkins Estimation-1973.I-1998.I

\begin{tabular}{|llll|}
\hline Currencies & Consumer price & Wholesale price & Unit labor cost \\
\hline French Franc & Stationary Process & $r_{t}-r_{t-1}=\varepsilon_{t}-0.36 \varepsilon_{t-9(0.09)}$ & Stationary Process \\
Dutch Guilder & $r_{t}-r_{t-1}=\varepsilon_{t}-0.35 \varepsilon_{t-8(0.10)}$ & $r_{t}-r_{t-1}=\varepsilon_{t}-0.26 \varepsilon_{t-1(0.09)}$ & $r_{t}-r_{t-1}=\varepsilon_{t}$ \\
Belgian Franc & $r_{t}-r_{t-1}=\varepsilon_{t}-0.21 \varepsilon_{t-1(0.10)}$ & $r_{t}-r_{t-1}=\varepsilon_{t}$ & $r_{t}-r_{t-1}=\varepsilon_{t}$ \\
Italian Lira & $r_{t}-r_{t-1}=\varepsilon_{t}$ & Stationary Process & $r_{t}-r_{t-1}=\varepsilon_{t}-0.28 \varepsilon_{t-8(0.10)}$ \\
Spanish Peseta & $r_{t}-r_{t-1}=\varepsilon_{t}$ & Stationary Process & $r_{t}-r_{t-1}=\varepsilon_{t}-0.24 \varepsilon_{t-7(0.09)}$ \\
Portuguese Es. & $r_{t}-r_{t-1}=\varepsilon_{t}$ & NA & NA \\
Austrian Shil. & $r_{t}-r_{t-1}=\varepsilon_{t}$ & $r_{t}-r_{t-1}=\varepsilon_{t}$ & Trend-stationary Process \\
Finnish Mark. & $r_{t}-r_{t-1}=\varepsilon_{t}$ & $r_{t}-r_{t-1}=\varepsilon_{t}$ & $r_{t}-r_{t-1}=\varepsilon_{t}$ \\
Irish Punt & $r_{t}-r_{t-1}=\varepsilon_{t}$ & $r_{t}-r_{t-1}=\varepsilon_{t}$ & $r_{t}-r_{t-1}=\varepsilon_{t}$ \\
Greek Drachma & Stationary Process & Stationary Process & $r_{t}-r_{t-1}=\varepsilon_{t}-0.36 \varepsilon_{t-1(0.09)}$ \\
Swedish Kr. & ARMA $(1,1)$ ou AR(1) & Stationary Process & Trend-stationary Process \\
Danish Krone & Stationary Process & & \\
Sterling Pound & $r_{t}-r_{t-1}=\varepsilon_{t}$ & Stationary Process & NA \\
\hline
\end{tabular}

Note: Standard errors in parenthesis.

same method applied to the Dutch Guilder exchange rate also reveals the presence of correlated errors, but of MA(8) type. On the other hand for Portugal, Finland and Denmark, significant correlation in the residuals is not established. For three countries, the hypothesis of unit root is not acceptable: the real exchange rates of France and Greece seem stationary in level, while an ARIMA $(1,0,1)$ process can perfectly model the real exchange rate of Sweden. 


\section{Wholesale Prices}

Results are more contrasted: for only three countries (Belgium, Ireland and United Kingdom) is the presence of unit-root accepted without ambiguity. For Austria and Finland, a finer study indicates the presence of a simple random walk while for the Netherlands we discover the presence of a MA(1) part. For France, the time series can be modeled by an $\operatorname{ARIMA}(0,1,9)$ process that is a process with a unit-root and correlated errors. For the other countries, nonstationarity is not clearly established and the series can be modeled by high orders ARMA processes.

\section{Unit Labor Costs}

There is no contradiction for the real exchange rates of five countries: Netherlands, Belgium, Finland, Ireland and United Kingdom, which all contain a unit-root. The presence of correlated errors for Italy (MA (8)), Spain (MA (7)) and Greece (MA (1)) is established. As regards Sweden and Austria, ADF3, PP2 and KPSS2 tests allow identifying a stationary trend process. The decision is more difficult for France and a high order stationary ARMA process should be fitted on this series.

Theses results show that globally, the presence of unit root in the real exchange rates is better verified for consumer prices and unit labor costs than for wholesale prices. This militates in favor of the rejection of a broad definition of the PPP (nontradable and tradable goods). However, we remark that the unit root hypothesis is rejected with consumer prices for France and Greece. Between Germany and these two countries, PPP can be accepted ${ }^{11}$.

Furthermore, we note that in many cases the tests do not yield clear conclusions. We can explain this finding by the presence of moving average processes but also by shifts in European monetary regimes. Hence, it is necessary to complete this work by using tests allowing for the presence of a trend break.

\section{Tests for a Unit-root and Breaks Hypotheses}

During the period 1973-1998, many important events occurred. In the first place, there was an exchange rate regime shift: from the Snake to the EMS in 1979. Some countries came later into the system (see annex1). Secondly, a marked stability of the exchange rates may be observed from 1987 to 1992, reflecting the convergence of monetary policies ("new EMS" of Gavazzi and Giovannini,

\footnotetext{
${ }^{11}$ CROUHY-VEYRAC and SAINT MARC (1995 p. 134) obtain the same results (period 1971-1990).
} 
Table 5. Results of the estimations of Perron's Models (1997)

\begin{tabular}{|c|c|c|c|}
\hline Series & Model 1 & Model 2 & Model 3 \\
\hline French Franc: CPI & Reject H0 & Reject H0 & Reject H0. \\
\hline WPI & Unit Root & Unit Root & Unit Root \\
\hline ULC & Reject H0 & Reject H0 & Unit Root \\
\hline Dutch Guilder: CPI & Unit Root & Unit Root & Unit Root \\
\hline WPI & Reject H0 & Reject H0 & Reject H0 \\
\hline ULC & Unit Root & Unit Root & Unit Root \\
\hline Belgian Franc: CPI & Reject H0 & Reject H0 & Unit Root \\
\hline WPI & Reject H0 & Reject HO & Unit Root \\
\hline ULC & Unit Root & Reject HO & Reject H0 \\
\hline Italian Lira: CPI & Reject H0 & Unit Root & Unit Root \\
\hline WPI & Reject H0 & Reject H0 & Unit Root \\
\hline ULC & Unit Root & Unit Root & Unit Root \\
\hline Spanish Peseta: CPI & Unit Root & Unit Root & Unit Root \\
\hline WPI & Unit Root & Unit Root & Unit Root \\
\hline ULC & Unit Root & Unit Root & Unit Root \\
\hline Port. Escudo: CPI & Reject H0 & Unit Root & Reject H0 \\
\hline Austr. Shilling: CPI & Unit Root & Reject HO & Reject HO \\
\hline WPI & Reject H0 & Reject HO & Reject H0 \\
\hline ULC & Unit Root & Unit Root & Unit Root \\
\hline Fin. Markka: CPI & Reject H0 & Reject H0 & Reject H0 \\
\hline WPI & Reject H0 & Reject H0 & Reject H0 \\
\hline ULC & Reject H0 & Reject H0. & Reject H0 \\
\hline Irish Punt: CPI & Unit Root & Unit Root & Unit Root \\
\hline WPI & Unit Root & Unit Root & Unit Root \\
\hline ULC & Unit Root & Unit Root & Unit Root \\
\hline Gr. Drachma: CPI & Reject H0 & Reject H0 & Unit Root \\
\hline WPI & Unit Root & Reject H0 & Unit Root \\
\hline ULC & Unit Root & Unit Root & Unit Root \\
\hline Swedish Krone: CPI & Reject H0 & Unit Root & Unit Root \\
\hline WPI & Reject H0 & Reject HO & Unit Root \\
\hline ULC & Reject H0 & Unit Root & Unit Root \\
\hline Danish Krone: CPI & Unit Root & Unit Root & Unit Root \\
\hline WPI & Unit Root & Unit Root & Unit Root \\
\hline Sterling Pound: CPI & Unit Root & Unit Root & Unit Root \\
\hline WPI & Unit Root & Unit Root & Unit Root \\
\hline ULC & Unit Root & Unit Root & Unit Root \\
\hline
\end{tabular}

1989). In the third place, we have two exchange crises in September 1992 and August 1993. For example, the United Kingdom and Italy withdrew from the exchange rate mechanism. For these reasons, we think that these events (shocks) may be at the origin of breaks with a change in the intercept of the trend function 
and/or a change in the slope of the trend function. In this case, it is possible that most macroeconomic series, here the real exchange rates, are not characterized by the presence of a unit-root but are «trend-stationary » ${ }^{12}$ (see the previous papers of Perron, 1989, 1990; Rappoport and Reichlin, 1989; Evans, 1989). But, if it is true, the choice of the time break is essential.

Following Banerjee and et al. (1992), Zivot and Andrews (1992), Christiano (1992), we admit that it is not possible to choose the dates ex-post (after looking at the data), because these dates are correlated with the data. We must consider that a shift in trend arises at an unknown time a priori. Perron (1997), Vogelsang and Perron $(1998)^{13}$ propose additional tests for a unit root allowing for breaks. We follow Perron (1997), and we study three models: the first (Model 1) allows for a change in the intercept; the second one (Model 2) accepts both a change in the intercept and the slope; and under the third model (Model 3), a change in the slope is allowed but both segments of the trend function are joined at the time of the break. A synthesis of these estimations ${ }^{14}$ is presented in Table 5 .

The results show that:

1- In 6 cases, the three Perron's models give opposite conclusions: these are Spanish peseta (WPI), Dutch guilder (WPI), Danish krone (WPI) and Finnish markka (CPI, WPI and ULC). For the Finnish markka, the charts point to a very strong break in 1991. For the others currencies, we note that these results are in favor of PPP for traded goods.

2- In 16 cases, the three models give same results as before.

3- In 14 cases, some estimations confirm the previous results and some are different. Here, a decisive conclusion is more difficult, insofar as it depends on the model. In addition, the observations of the charts do not always permit a clear choice between the models.

With a few exceptions, the behavior of the real exchange rates is not modified when we introduce a break in the series. Note also that the break dates for most series (see annex 4) are different from the dates of entry in the EMS. We can say that these results are not directly sensitive to the exchange rates regime shifts (the date of 1979 , or approximately ${ }^{15}$, is not usually selected), but depend more on

\footnotetext{
${ }^{12}$ In this case, the series can be modeled as stationary around a deterministic breaking trend function (PERRON, 1989, 1997).

${ }^{13}$ See also MONTANES and REYES (1998).

${ }^{14}$ For more details, see annex 4.

${ }^{15}$ As PERRON (1997 p. 376) notice, « the breaks dates should be viewed as approximate ».
} 
monetary policies changes or exchange crises.

Hence, these tests do not always allow us to conclude in favor of the presence or absence of unit-root in the real exchange rates. Some doubts remain for the choice of the relevant model. It is therefore necessary to complete this analysis by estimations of the fractional differencing parameter of these rates.

\section{Fractional Dynamics in European Real Exchange Rates}

Diebold et al. (1991), Cheung (1993), Barkoulas and Baum (1998) or Baum and al. (1998), showed that exchange rates could behave as fractional processes, that is processes for which the degree of integration $(d)$ is not an integer.

Two cases appear quite frequently in studies on monetary and financial variables. One is said to exhibit long memory, or long-range positive dependence, although these variables satisfy the condition of stationarity $(0<d<0.5)$. Secondly, there are mean-reverting processes, which are not stationary $(0.5<d<1)$, but reveal a tendency to return towards its mean value.

After a brief presentation of fractional processes (A), we will proceed with an estimation of the degree of integration (B).

\section{A. Model of Fractional Integration and Methods of Estimation}

An ARFIMA ${ }^{16}$ process can be represented as an ARIMA process for which the degree of integration is not an integer. Equation (3) stays the same

$$
\Phi(B)(I-B)^{d} r_{t}=\Theta(B) \varepsilon_{t}, \varepsilon_{t} \sim\left(0, \sigma^{2}\right)
$$

but $(I-B)^{d}$ is defined by his polynomial expansion:

$$
(I-B)^{d}=\sum_{k=0}^{\infty} \frac{\Gamma(k-d) B^{k}}{\Gamma(-d) \Gamma(k+1)}=1-d B+\frac{d(d-1)}{2 !} B^{2}-\frac{d(d-1)(d-2)}{3 !} B^{3}+\ldots
$$

with denoting the gamma function

The first step to estimate $d$ consists in differencing the series and in estimating $\tilde{d}$ in the model $(I-B)^{\tilde{d}} X_{t}=\Phi^{-1}(B) \Theta(B) \varepsilon_{t} \equiv u_{t}$ where $X_{t}=\left(r_{t}-r_{t-1}\right) . \tilde{d}$ is the degree of integration of the variable $X$, i.e. the relative variations of the real exchange rate. From the estimation of $\tilde{d}$, one will be able to deduct the degree of

\footnotetext{
${ }^{16}$ See GRANGER and JOYEUX (1980), and HOSKING (1981).

${ }^{17}$ We consider that the spectral density, noted $f(\xi)$, behave as $f(\xi) \sim G \xi^{1-2 H}$, when $\xi \rightarrow 0^{+}$, for $G \in(0, \infty)$ and $H \in(0,1)$
} 
Table 6. Empirical Estimates of the Fractional-Differencing Parameter d for the Real Exchange Rates Consumer Price 1973.I-1998.I

\begin{tabular}{|c|c|c|c|c|c|c|}
\hline & \multicolumn{3}{|c|}{ Spectral Regression Estimations } & \multicolumn{3}{|c|}{ Gaussian Semiparametric Estimations } \\
\hline Currencies & $\mathrm{d}(\mathbf{0 . 5})$ & $\mathrm{d}(\mathbf{0 . 5 2 5})$ & $\mathrm{d}(\mathbf{0 . 5 5})$ & $\mathrm{d}(\mathbf{0 . 5})$ & $\mathrm{d}(\mathbf{0 . 5 2 5})$ & $\mathrm{d}(\mathbf{0 . 5 5})$ \\
\hline French Franc & $\begin{array}{l}-0.756 \\
(-2.575)^{* *}\end{array}$ & $\begin{array}{l}-0.569 \\
(-2.074) * *\end{array}$ & $\begin{array}{l}-0.523 \\
(-2.028)^{* *}\end{array}$ & $\begin{array}{l}-0.640 \\
(-4.047)^{* *}\end{array}$ & $\begin{array}{l}-0.570 \\
(-3.781)^{* *}\end{array}$ & $\begin{array}{l}-0.500 \\
(-3.464)^{* *}\end{array}$ \\
\hline Dutch Guilder & $\begin{array}{l}0.512 \\
(1.747)^{*}\end{array}$ & $\begin{array}{l}0.506 \\
(1.846)^{*}\end{array}$ & $\begin{array}{l}0.421 \\
(1.631)^{*}\end{array}$ & $\begin{array}{l}0.350 \\
(2.213)^{* *}\end{array}$ & $\begin{array}{l}0.4900 \\
(3.250)^{* *}\end{array}$ & $\begin{array}{l}0.410 \\
(2.840)^{* *}\end{array}$ \\
\hline Belgian Franc & $\begin{array}{l}-0.142 \\
(-0.484)\end{array}$ & $\begin{array}{l}-0.160 \\
(-0.583)\end{array}$ & $\begin{array}{l}-0.184 \\
(-0.711)\end{array}$ & $\begin{array}{l}-0.100 \\
(-0.632)\end{array}$ & $\begin{array}{l}-0.080 \\
(-0.531)\end{array}$ & $\begin{array}{l}-0.080 \\
(-0.554)\end{array}$ \\
\hline Italian Lira & $\begin{array}{l}0.020 \\
(0.069)\end{array}$ & $\begin{array}{l}-0.028 \\
(-0.103)\end{array}$ & $\begin{array}{l}-0.053 \\
(-0.208)\end{array}$ & $\begin{array}{l}-0.020 \\
(-0.126)\end{array}$ & $\begin{array}{l}-0.030 \\
(-0.199)\end{array}$ & $\begin{array}{l}-0.040 \\
(-0.277)\end{array}$ \\
\hline Spanish Peseta & $\begin{array}{l}-0.159 \\
(-0.543)\end{array}$ & $\begin{array}{l}-0.028 \\
(-0.104)\end{array}$ & $\begin{array}{l}0.405 \\
(1.570)\end{array}$ & $\begin{array}{l}-0.160 \\
(-1.011)\end{array}$ & $\begin{array}{l}-0.070 \\
(-0.464)\end{array}$ & $\begin{array}{l}0.04 \\
0(0.277)\end{array}$ \\
\hline $\begin{array}{l}\text { Portuguese } \\
\text { Escudo }\end{array}$ & $\begin{array}{l}-0.354 \\
(-1.205)\end{array}$ & $\begin{array}{l}-0.214 \\
(-0.781)\end{array}$ & $\begin{array}{l}-0.153 \\
(-0.593)\end{array}$ & $\begin{array}{l}-0.310 \\
(-1.961)^{*}\end{array}$ & $\begin{array}{l}-0.140 \\
(-0.928)\end{array}$ & $\begin{array}{l}0.010 \\
(0.069)\end{array}$ \\
\hline Austrian Shilling & $\begin{array}{l}0.064 \\
(0.219)\end{array}$ & $\begin{array}{l}0.123 \\
(0.452)\end{array}$ & $\begin{array}{l}0.064 \\
(0.219)\end{array}$ & $\begin{array}{l}0.0001 \\
(0.0001)\end{array}$ & $\begin{array}{l}0.060 \\
(0.397)\end{array}$ & $\begin{array}{l}0.040 \\
(0.277)\end{array}$ \\
\hline Finnish Markka & $\begin{array}{l}0.0815 \\
(0.278)\end{array}$ & $\begin{array}{l}0.290 \\
(1.058)\end{array}$ & $\begin{array}{l}0.379 \\
(1.468)\end{array}$ & $\begin{array}{l}0.010 \\
(0.063)\end{array}$ & $\begin{array}{l}0.140 \\
(0.928)\end{array}$ & $\begin{array}{l}0.270 \\
(1.870)^{*}\end{array}$ \\
\hline Irish Punt & $\begin{array}{l}-0.069 \\
(-0.236)\end{array}$ & $\begin{array}{l}0.031 \\
(0.113)\end{array}$ & $\begin{array}{l}0.073 \\
(0.283)\end{array}$ & $\begin{array}{l}-0.010 \\
(-0.063)\end{array}$ & $\begin{array}{l}0.050 \\
(0.331)\end{array}$ & $\begin{array}{l}0.080 \\
(0.554)\end{array}$ \\
\hline Greek Drachma & $\begin{array}{l}-0.572 \\
(-1.947)^{* *}\end{array}$ & $\begin{array}{l}-0.432 \\
(-1.576)\end{array}$ & $\begin{array}{l}-0.411 \\
(-1.591)\end{array}$ & $\begin{array}{l}-0.230 \\
(-1.454)\end{array}$ & $\begin{array}{l}-0.140 \\
(-0.928)\end{array}$ & $\begin{array}{l}-0.090 \\
(-0.623)\end{array}$ \\
\hline Swedish Krone & $\begin{array}{l}-0.362 \\
(-1.234)\end{array}$ & $\begin{array}{l}-0.190 \\
(-0.694)\end{array}$ & $\begin{array}{l}-0.146 \\
(-0.565)\end{array}$ & $\begin{array}{l}-0.450 \\
(-2.846)^{* *}\end{array}$ & $\begin{array}{l}-0.270 \\
(-1.791)^{*}\end{array}$ & $\begin{array}{l}-0.130 \\
(-0.900)\end{array}$ \\
\hline Danish Krone & $\begin{array}{l}0.0923 \\
(0.315)\end{array}$ & $\begin{array}{l}-0.058 \\
(-0.212)\end{array}$ & $\begin{array}{l}-0.179 \\
(-0.694)\end{array}$ & $\begin{array}{l}0.040 \\
(0.252)\end{array}$ & $\begin{array}{l}-0.130 \\
(-0.862)\end{array}$ & $\begin{array}{l}-0.220 \\
(-1.524)\end{array}$ \\
\hline Sterling Pound & $\begin{array}{l}-0.260 \\
(-0.886)\end{array}$ & $\begin{array}{l}0.100 \\
(0.367)\end{array}$ & $\begin{array}{l}0.195 \\
(0.757)\end{array}$ & $\begin{array}{l}-0.180 \\
(-1.138)\end{array}$ & $\begin{array}{l}-0.080 \\
(-0.531)\end{array}$ & $\begin{array}{l}0.010 \\
(0.069)\end{array}$ \\
\hline
\end{tabular}

Notes: $\mathrm{d}(0.5), \mathrm{d}(0.525)$ et $\mathrm{d}(0.55)$ give the $\mathrm{d}$ estimates corresponding to estimation sample size $v=T^{0.5}, v=T^{0.525}, v=T^{0.55}$.

The t-statistics are given in parentheses, and are constructed imposing the known theoretical error variance of $\pi^{2} / 6 . * *$ and $*$ indicate significance at 5 percent and 10 percent.

integration $(d)$ from the real exchange rate in level (in logarithm), knowing that $d=1+\tilde{d}$. Notice that testing hypothesis $\tilde{d}=0$ for $X$, is equivalent to testing the hypothesis of a unit-root in $r$.

To estimate $\tilde{d}$, two procedures will be used successively: the semi-parametric one suggested by Geweke and Porter-Hudak (1983), and the Gaussian semiparametric procedure developed by Robinson (1995).

Geweke and Porter Hudak's procedure (GPH) is based on the slope of a spectral density function. More exactly, if the periodogram of $X$ of frequency $\xi$ is defined by $I(\xi)=\frac{1}{2 \pi}\left|\Sigma_{t=1}^{n} e^{i t \xi}\left(X_{t=1}-\bar{X}\right)\right|^{2}$ with $\bar{X}=\frac{1}{n} \mid \Sigma_{t=1}^{n} X_{t}$, then the spectral regression is 
Table 7. Empirical Estimates of the Fractional-Differencing Parameter d for the Real Exchange Rates Wholesale Price 1973.I-1998.I

\begin{tabular}{|c|c|c|c|c|c|c|}
\hline & \multicolumn{3}{|c|}{ Spectral Regression Estimations } & \multicolumn{3}{|c|}{ Gaussian Semiparametric Estimations } \\
\hline Currencies & $\mathrm{d}(0.5)$ & $\mathrm{d}(0.525)$ & $\mathrm{d}(0.55)$ & $\mathrm{d}(0.5)$ & $\mathrm{d}(0.525)$ & $\mathrm{d}(0.55)$ \\
\hline French Franc & $\begin{array}{l}0.180 \\
(0.614)\end{array}$ & $\begin{array}{l}0.141 \\
(0.515)\end{array}$ & $\begin{array}{l}0.316 \\
(1.225)\end{array}$ & $\begin{array}{l}-0.130 \\
(-0.822)\end{array}$ & $\begin{array}{l}-0.030 \\
(-0.199)\end{array}$ & $\begin{array}{l}0.170 \\
(1.177)\end{array}$ \\
\hline Dutch Guilder & $\begin{array}{l}-0.139 \\
(-0.475)\end{array}$ & $\begin{array}{l}-0.201 \\
(-0.733)\end{array}$ & $\begin{array}{l}-0.112 \\
(-0.436)\end{array}$ & $\begin{array}{l}-0.370 \\
(-2.340)^{* *}\end{array}$ & $\begin{array}{l}-0.340 \\
(-2.255)^{* *}\end{array}$ & $\begin{array}{l}-0.240 \\
(-1.663)^{*}\end{array}$ \\
\hline Belgian Franc & $\begin{array}{l}-0.076 \\
(-0.260)\end{array}$ & $\begin{array}{l}-0.118 \\
(-0.432)\end{array}$ & $\begin{array}{l}-0.167 \\
(-0.645)\end{array}$ & $\begin{array}{l}-0.030 \\
(-0.189)\end{array}$ & $\begin{array}{l}-0.060 \\
(-0.397)\end{array}$ & $\begin{array}{l}-0.100 \\
(-0.692)\end{array}$ \\
\hline Italian Lira & $\begin{array}{l}-0.393 \\
(-1.341)\end{array}$ & $\begin{array}{l}-0.362 \\
(-1.320)\end{array}$ & $\begin{array}{l}-0.282 \\
(-1.094)\end{array}$ & $\begin{array}{l}-0.370 \\
(-2.340)^{* *}\end{array}$ & $\begin{array}{l}-0.320 \\
(-2.122) * *\end{array}$ & $\begin{array}{l}-0.240 \\
(-1.663) *\end{array}$ \\
\hline Spanish Peseta & $\begin{array}{l}-0.349 \\
(-1.190)\end{array}$ & $\begin{array}{l}-0.220 \\
(-0.802)\end{array}$ & $\begin{array}{l}0.006 \\
(0.026)\end{array}$ & $\begin{array}{l}-0.320 \\
(-2.024) * *\end{array}$ & $\begin{array}{l}-0.220 \\
(-1.459)\end{array}$ & $\begin{array}{l}-0.110 \\
(-0.762)\end{array}$ \\
\hline Portu & NA & & & & & \\
\hline $\begin{array}{l}\text { Austrian Shil- } \\
\text { ling }\end{array}$ & $\begin{array}{l}0.039 \\
(0.135)\end{array}$ & $\begin{array}{l}0.129 \\
(0.473)\end{array}$ & $\begin{array}{l}0.208 \\
(0.808)\end{array}$ & $\begin{array}{l}-0.0 \\
(-0.2\end{array}$ & $\begin{array}{l}0.020 \\
(0.132)\end{array}$ & $\begin{array}{l}0.090 \\
(0.623)\end{array}$ \\
\hline Finnish Markka & $\begin{array}{l}-0.082 \\
(-0.280)\end{array}$ & $\begin{array}{l}0.140 \\
(0.510)\end{array}$ & $\begin{array}{l}0.241 \\
(0.937)\end{array}$ & $\begin{array}{l}-0.0 \\
(-0.5\end{array}$ & $\begin{array}{l}0.060 \\
(0.397)\end{array}$ & $\begin{array}{l}0.200 \\
(1.385)\end{array}$ \\
\hline Irish Punt & $\begin{array}{l}-0.249 \\
(-0.849)\end{array}$ & $\begin{array}{l}-0.099 \\
(-0.362)\end{array}$ & $\begin{array}{l}-0.143 \\
(-0.556)\end{array}$ & $\begin{array}{l}-0.290 \\
(-1.834)^{*}\end{array}$ & $\begin{array}{l}-0.230 \\
(-1.526)\end{array}$ & $\begin{array}{l}-0.240 \\
(-1.663)^{*}\end{array}$ \\
\hline Greek Drachma & $\begin{array}{l}-0.414 \\
(-1.412)\end{array}$ & $\begin{array}{l}-0.368 \\
(-1.343)\end{array}$ & $\begin{array}{l}-0.366 \\
(-1.418)\end{array}$ & $\begin{array}{l}-0.230 \\
(-1.454)\end{array}$ & $\begin{array}{l}-0.180 \\
(-1.193)\end{array}$ & $\begin{array}{l}-0.140 \\
(-0.969)\end{array}$ \\
\hline Swedish Krone & $\begin{array}{l}-0.166 \\
(-0.566)\end{array}$ & $\begin{array}{l}-0.025 \\
(-0.092)\end{array}$ & $\begin{array}{l}-0.0201 \\
(-0.078)\end{array}$ & $\begin{array}{l}-0.350 \\
(-2.213)^{* *}\end{array}$ & $\begin{array}{l}-0.210 \\
(-1.392)\end{array}$ & $\begin{array}{l}-0.130 \\
(-0.901)\end{array}$ \\
\hline Danish Krone & $\begin{array}{l}-0.406 \\
(-1.384)\end{array}$ & $\begin{array}{l}-0.434 \\
(-1.584)\end{array}$ & $\begin{array}{l}-0.447 \\
(-1.733)^{*}\end{array}$ & $\begin{array}{l}-0.340 \\
(-2.150)^{* *}\end{array}$ & $\begin{array}{l}-0.360 \\
(-2.387)^{* *}\end{array}$ & $\begin{array}{l}-0.360 \\
(-2.494) * *\end{array}$ \\
\hline Sterling Pound & $\begin{array}{l}-0.250 \\
(-0.852)\end{array}$ & $\begin{array}{l}0.168 \\
(0.613)\end{array}$ & $\begin{array}{l}0.202 \\
(0.784)\end{array}$ & $\begin{array}{l}-0.320 \\
(-2.024) * *\end{array}$ & $\begin{array}{l}-0.250 \\
(-1.658)^{*}\end{array}$ & $\begin{array}{l}-0.180 \\
(-1.247)\end{array}$ \\
\hline
\end{tabular}

Notes: $\mathrm{d}(0.5), \mathrm{d}(0.525)$ et $\mathrm{d}(0.55)$ give the $\mathrm{d}$ estimates corresponding to estimation sample size $v=T^{0.5}, v=T^{0.525}, v=T^{0.55}$.

The t-statistics are given in parentheses, and are constructed imposing the known theoretical error variance of $\pi^{2} / 6 . * *$ and $*$ indicate significance at 5 percent and 10 percent.

$$
\ln \left\{I\left(\xi_{\lambda}\right)\right\}=\beta_{0}+\beta_{1} \ln \left\{4 \sin ^{2}\left(\frac{\xi_{\lambda}}{2}\right)\right\}+\eta_{l}, \lambda=1, \ldots, v
$$

with $\xi_{\lambda}=\frac{2 \pi \lambda}{n}, n$ the number of observations, and $v=g(n)<<n$ the number of Fourier frequencies included in the regression. In practice, one will retain $g(n)=$ $\operatorname{int}\left|n^{a}\right|$, int [ ] being the integer part of any real number and $\alpha$ will successively take the values $0.5,0.525,0.55$. Furthermore, the variance $\eta_{\lambda}$ of is supposed known and fixed to $\pi^{2} / 6$ (cf. Geweke and Porter-Hudak (1983)). The negative of the Ordinary Least Squares estimation of the slope coefficient of the regression, that is $-\hat{\beta}_{1}$, will 
Table 8. Empirical Estimates of the Fractional-Differencing Parameter d for the Real Exchange Rates Unit Labor Costs 1973.I-1998.I

\begin{tabular}{|c|c|c|c|c|c|c|}
\hline & \multicolumn{3}{|c|}{ Spectral Regression Estimations } & \multicolumn{3}{|c|}{ Gaussian Semiparametric Estimations } \\
\hline Currencies & $\mathrm{d}(0.5)$ & $\mathrm{D}(0.525)$ & $\mathrm{d}(0.55)$ & $\mathrm{d}(0.5)$ & $\mathrm{d}(0.525)$ & $\mathrm{d}(0.55)$ \\
\hline French Franc & $\begin{array}{l}-0.472 \\
(-1.607)^{*}\end{array}$ & $\begin{array}{l}-0.362 \\
(-1.320)\end{array}$ & $\begin{array}{l}-0.366 \\
(-1.418)\end{array}$ & $\begin{array}{l}-0.490 \\
(-3.099) * *\end{array}$ & $\begin{array}{l}-0.430 \\
(-2.852)^{* *}\end{array}$ & $\begin{array}{l}-0.400 \\
(-2.771)^{* *}\end{array}$ \\
\hline Dutch Guilder & $\begin{array}{l}0.089 \\
(0.306)\end{array}$ & $\begin{array}{l}0.253 \\
(0.923)\end{array}$ & $\begin{array}{l}0.222 \\
(0.862)\end{array}$ & $\begin{array}{l}-0.040 \\
(-0.253)\end{array}$ & $\begin{array}{l}0.010 \\
(0.066)\end{array}$ & $\begin{array}{l}0.040 \\
(0.277)\end{array}$ \\
\hline Belgian Franc & $\begin{array}{l}-0.076 \\
(-0.259)\end{array}$ & $\begin{array}{l}-0.084 \\
(-0.305)\end{array}$ & $\begin{array}{l}-0.078 \\
(-0.303)\end{array}$ & $\begin{array}{l}-0.060 \\
(-0.379)\end{array}$ & $\begin{array}{l}-0.060 \\
(-0.398)\end{array}$ & $\begin{array}{l}-0.020 \\
(-0.138)\end{array}$ \\
\hline Italian Lira & $\begin{array}{l}-0.191 \\
(-0.651)\end{array}$ & $\begin{array}{l}-0.183 \\
(-0.668)\end{array}$ & $\begin{array}{l}-0.295 \\
(-1.144)\end{array}$ & $\begin{array}{l}-0.290 \\
(-1.834)^{*}\end{array}$ & $\begin{array}{l}-0.230 \\
(-1.526)\end{array}$ & $\begin{array}{l}-0.340 \\
(-2.355) * *\end{array}$ \\
\hline Spanish Peseta & $\begin{array}{l}-0.245 \\
(-0.837)\end{array}$ & $\begin{array}{l}-0.207 \\
(-0.753)\end{array}$ & $\begin{array}{l}-0.099 \\
(-0.385)\end{array}$ & $\begin{array}{l}-0.270 \\
(-1.708)^{*}\end{array}$ & $\begin{array}{l}-0.210 \\
(-1.393)\end{array}$ & $\begin{array}{l}-0.130 \\
(-0.900)\end{array}$ \\
\hline Portuguese Esc. & NA & & & & & \\
\hline $\begin{array}{l}\text { Austrian Shil- } \\
\text { ling }\end{array}$ & $\begin{array}{l}0.015 \\
(0.051)\end{array}$ & $\begin{array}{l}0.068 \\
(0.248)\end{array}$ & $\begin{array}{l}-0.007 \\
(-0.030)\end{array}$ & $\begin{array}{l}-0.060 \\
(-0.379)\end{array}$ & $\begin{array}{l}0.100 \\
(0.663)\end{array}$ & $\begin{array}{l}0.020 \\
(0.138)\end{array}$ \\
\hline Finnish Markka & $\begin{array}{l}0.003 \\
(0.011)\end{array}$ & $\begin{array}{l}0.136 \\
(0.498)\end{array}$ & $\begin{array}{l}0.300 \\
(1.164)\end{array}$ & $\begin{array}{l}-0.140 \\
(-0.885)\end{array}$ & $\begin{array}{l}0.020 \\
(0.132)\end{array}$ & $\begin{array}{l}0.200 \\
(1.386)\end{array}$ \\
\hline Irish Punt & $\begin{array}{l}-0.054 \\
(-0.185)\end{array}$ & $\begin{array}{l}0.116 \\
(0.425)\end{array}$ & $\begin{array}{l}0.024 \\
(0.096)\end{array}$ & $\begin{array}{l}0.050 \\
(0.316)\end{array}$ & $\begin{array}{l}0.130 \\
(0.862)\end{array}$ & $\begin{array}{l}-0.040 \\
(-0.277)\end{array}$ \\
\hline Greek Drachma & $\begin{array}{l}-0.062 \\
(-0.212)\end{array}$ & $\begin{array}{l}-0.036 \\
(-0.133)\end{array}$ & $\begin{array}{l}-0.084 \\
(-0.327)\end{array}$ & $\begin{array}{l}-0.030 \\
(-0.189)\end{array}$ & $\begin{array}{l}0.010 \\
(0.066)\end{array}$ & $\begin{array}{l}-0.020 \\
(-0.138)\end{array}$ \\
\hline Swedish Krone & $\begin{array}{l}-0.327 \\
(-1.115)\end{array}$ & $\begin{array}{l}-0.148 \\
(-0.542)\end{array}$ & $\begin{array}{l}-0.076 \\
(-0.295)\end{array}$ & $\begin{array}{l}-0.380 \\
(-2.403)^{* *}\end{array}$ & $\begin{array}{l}-0.220 \\
(-1.459)\end{array}$ & $\begin{array}{l}-0.070 \\
(-0.485)\end{array}$ \\
\hline Danish Krone & NA & & & & & \\
\hline Sterling Pound & $\begin{array}{l}-0.093 \\
(-0.316)\end{array}$ & $\begin{array}{l}0.027 \\
(0.098)\end{array}$ & $\begin{array}{l}0.102 \\
(0.397)\end{array}$ & $\begin{array}{l}-0.130 \\
(-0.822)\end{array}$ & $\begin{array}{l}-0.040 \\
(-0.265)\end{array}$ & $\begin{array}{l}0.050 \\
(0.346)\end{array}$ \\
\hline
\end{tabular}

Notes: $\mathrm{d}(0.5), \mathrm{d}(0.525)$ et $\mathrm{d}(0.55)$ give the $\mathrm{d}$ estimates corresponding to estimation sample size $v=T^{0.5}, v=T^{0.525}, v=T^{0.55}$.

The t-statistics are given in parentheses, and are constructed imposing the known theoretical error variance of $\pi^{2} / 6 . * *$ and $*$ indicate significance at 5 percent and 10 percent.

provide a consistent and asymptotically normal estimation of $\tilde{d}$.

Robinson's (1995) method is based on the estimation of a parameter $H$, noted $\hat{H}$, obtained by minimizing with respect to $H$ the function

$$
R(H)=\ln \hat{G}(H)-(2 H-1) 1 / v \cdot \sum_{\lambda=1}^{v} \ln \xi_{\lambda}^{17}
$$

where parameters have the same meaning that above and $\hat{G}(H)=1 / v \cdot \sum_{\lambda=1}^{v}$ $\xi_{\lambda}^{2 H-1} I\left(\xi_{\lambda}\right)$. An estimation of $\tilde{d}$ can be obtained, knowing that $H=\tilde{d}+1 / 2$.

\section{B. Results for the estimated degree of Integration}

The estimations of fractional differencing parameters are given in tables 6-8. 
Let us recall that the degree of integration of the real exchange rate in level, $d$, will be obtained by posing ${ }^{18} d=1+\tilde{d}$.

\section{Consumer Prices}

For most countries (Table 6), the parameters $d$ are not significantly different from zero, meaning that the real exchange rate in level behaves as a random walk. There are however some notorious exceptions.

*For two currencies, we obtain long memory processes (the degree of integration is included between 0 and 0.5 ). The first interesting case is that of the French Franc. All the estimations confirm the existence of a long memory process. This result is coherent with the previous conclusions that the real exchange rate between the French Franc and the DM is stationary over the period. The second case of a long memory process is that of the Drachma, which is compatible with the results of the unit-root tests.

**For two other currencies, the Swedish Krone and the Portuguese Escudo, some valuations give a fractional differencing parameter included between 0.5 and 1 , that is synonymous of a mean-reverting process. Note that for these rates, the unit-root tests did not yield clear conclusions.

***Finally, the results obtained for the Dutch Guilder confirm the nonstationarity of the real exchange rate in level.

\section{Wholesale Prices}

All the estimations (table 7) lead to conclude in the nonstationarity of the real exchange rates based on the wholesale prices. However, the Gaussian semiparametric estimates show that the nonstationarity is coherent with a mean-reverting process in seven cases : for the Guilder, the Lira, the Peseta, the Irish Punt, the Swedish and Danish Krones, and for the Pound Sterling. Note that for three of these currencies, the Guilder, the Lira and the Swedish Krone, the estimations of Perrons model concluded that the real rates are stationary.

Even if these different tests may give opposite conclusions on the presence of a unit-root, they strongly suggest the existence of mean-reversion in real exchange rates based on the WPI measures.

\footnotetext{
${ }^{18}$ One will note that estimates of the spectral density function realized on real exchange rates in level give identical results for the degree of integration.
} 


\section{Unit Labor Costs}

Globally, the results in the table 8 show that the real rates are non-stationary, with however some differences.

*For the French Franc, we have a $d$ value close to 0.5 , and it is difficult to distinguish between a stationary process or a mean-reverting process. Recall that the unit-root hypothesis was rejected in the previous tests (see tables 3 to $5)$.

**For three exchange rates, the Lira, the Peseta and the Swedish Krone, we can accept a mean-reverting process for the real exchange rate. These results are close to valuations obtained by the Box and Jenkins method (see table 4), that shows that for these various currencies the processes are more complex than the simple random walk.

\section{Concluding Remarks}

The analysis of the behavior of the various bilateral real exchange rates of the European currencies against the German Mark shows that globally PPP is not verified, since the hypothesis of non-stationarity is not rejected for the three definitions of real exchange rates (CPI,WPU,ULC). But the study allowed us to precise the following points:

1- Some conclusions on PPP may differ according to the choice of prices and costs index.

In order to understand these results, we can decompose the real exchange rate (see equation 2 above) as:

$$
E R_{t, \text { all } / i}^{\text {cpi }}=\frac{E_{t, \text { all } / i} \cdot P_{e, t}^{i^{\theta}} P_{n e, t}^{i^{1-\theta}}}{P_{e, t}^{a l l^{\theta}} P_{n e, t}^{a l l^{1-\theta}}}=\frac{E_{t, \text { all } i} \cdot P_{e, t}^{i}}{P_{e, t}^{a l l}} \cdot \frac{\left(P_{e, t}^{a l l} / P_{n e, t}^{a l l}\right)^{(1-\theta)}}{\left(P_{e, t}^{i} / P_{n e, t}^{i}\right)^{(1-\theta)}}
$$

where the general price level, measured by the consumer prices index (CPI) is made of traded goods prices $\left(P_{e}\right)$ and non-traded goods prices $\left(P_{n e}\right) . \theta$ and (1$\theta$ ) are the shares of traded and non-traded goods in the economy (we suppose the same value ${ }^{19}$ of $\theta$ for each country). With perfect competition, firms set prices to reflect unit labor costs (nominal wages adjusted for productivity) in each sector:

$$
\begin{aligned}
P_{e}^{i} & =w_{e}^{i} / a_{e}^{i} \\
P_{n e}^{i} & =w_{n e}^{i} / a_{n e}^{i}
\end{aligned}
$$

\footnotetext{
${ }^{19}$ This hypothesis simplifies the presentation, but does not modify the main results.
} 


$$
\begin{aligned}
& P_{e}^{\text {all }}=w_{e}^{\text {all }} / a_{e}^{\text {all }} \\
& P_{n e}^{\text {all }}=w_{n e}^{\text {all }} / a_{n e}^{\text {all }}
\end{aligned}
$$

where $w_{e}$ and $w_{n e}$ are the wage rates in the traded and nontraded sectors, and $a_{e}$ and $a_{n e}$ represent the productivity in the traded and nontraded goods. Substitution of (5) and (6) yields:

$$
E R_{t, \text { all } / i}^{c p i}=\frac{E_{t, \text { all } / i} \cdot P_{e, t}^{i}}{P_{e, t}^{\text {all }}}=\left[\frac{\left(w_{e, t}^{\text {all }} / a_{e, t}^{\text {all }}\right)}{E_{t, \text { all } / i} \cdot\left(w_{e, t}^{i} / a_{e, t}^{i}\right)}\right]^{1-\theta} \cdot\left[\frac{E_{t, \text { all } / i} \cdot\left(w_{n e, t}^{i} / a_{n e, t}^{i}\right)}{\left(w_{n e, t}^{a l l} / a_{n e, t}^{a l l}\right)}\right]^{1-\theta}
$$

The first term on the right hand side represents the real exchange rate for traded goods (here wholesale prices, noted $E R^{w p i}$ ), the second and third terms give the real exchange rates calculated with unit labor costs of traded sector (here approximated by the costs of the manufacturing industry; noted $E R^{\text {ulce }}$ ) and unit labor costs of nontraded sector (noted $E R^{\text {ulcne }}$ ), with:

$$
E R_{t, \text { all } / i}^{\text {ulce }}=\frac{E_{t, \text { all } / i} \cdot\left(w_{e, t}^{i} / a_{e, t}^{i}\right)}{\left(w_{e, t}^{\text {all }} / a_{e, t}^{\text {all }}\right)} \text { and } E R_{t, \text { all } / i}^{\text {ulcne }}=\frac{E_{t, \text { all } / i} \cdot\left(w_{n e, t}^{i} / a_{n e, t}^{i}\right)}{\left(w_{n e, t}^{\text {all }} / a_{n e, t}^{\text {all }}\right)}
$$

Equation (7) can be written as:

$$
E R_{t, \text { all } / i}^{c p i}=E R_{t, \text { all } / i}^{w p i} \cdot\left[\frac{1}{E R_{t, \text { all } / i}^{\text {ulce }}}\right]^{1-\theta} \cdot\left[E R_{t, \text { all } / i}^{\text {ulcne }}\right]^{1-\theta}
$$

or in logarithms

$$
\log \left(E R_{t, \text { all } / i}^{c p i}\right)=\log \left(E R_{t, \text { all } / i}^{w p i}\right)-(1-\theta)-\log \left(E R_{t, \text { all } / i}^{u l c e}\right)+(1-\theta) \cdot\left(E R_{t, \text { all } / i}^{u l c n e}\right)
$$

If $\log \left(E R_{t, a l l / i}^{c p i}\right)$ is stationary, two cases are possible: either all the terms on the right hand side are stationary, or there exists a cointegration relationship between non-stationary terms. For the Finnish Markka, with Perrons model, we are in the first case. For the French Franc and the Greek Drachma, we are rather in the second case.

If $\log \left(E R_{t, a l l / i}^{c p i}\right)$ is non-stationary, that is the more frequent case, some terms on the right are non stationary and there is no cointegration relationship. If for example $\log \left(E R_{t, a l l / i}^{w p i}\right)$ is stationarity, the nonstationarity of $\log \left(E R_{t, a l l / i}^{c p i}\right)$ may be explained by the nonstationarity of the real exchange rate defined as the relative unit costs.

2- At the statistical level, we show that the traditional alternative between stationary series and random walk is too narrow. The joint use of the unit-root 
tests, of the Box and Jenkins method and fractional integration tests allowed to specify better models of behavior of real rates. In particular, the estimation of the degrees of differencing $d$ show that with PPP based on the wholesale prices, we have mean-reverting processes, which confirms the existence of memory forces towards a fundamental equilibrium value, although the real exchange rates are non-stationary. Conversely, some real exchange rates based on consumer prices, though stationary, have long memory properties. These results can be interpreted as the reflection of an increased integration of the goods markets, even though it is still too early to speak about perfect integration. With respect to unit labor cost parity, there is a process of convergence, but it remains incomplete.

There is an important exception to these conclusions, that is the French Franc real exchange rate with CPI. Indeed, the Franc-Mark real exchange rate is always stationary and reveals, when we estimate the degree of integration, a long memory process. We can say that Casselian PPP is supported empirically. This finding also confirms similar evolutions of the tradable price relative to non-tradable for France and Germany. There is no productivity bias (Balassa's bias). One can assume a process of real convergence between these two economies, that will not be surprising, given the narrow trade links between France and Germany. But one can also think that it reflects the convergence of the French and German economic policies, notably since the 1980 's. The policy of a "strong Franc" which led French authorities to gradually tighten their monetary policy certainly contributed to stabilize the real exchange rate. These results also show that membership of currencies in the European mechanisms of exchange (snake and EMS) had no decisive influence on real exchange rates. So the Guilder and the Belgian Franc real rates against Deutchmark are not stationary, while nominal exchange rates between these currencies remained very stable over the period.

Finally, it is difficult to compare these results with others, because few were dedicated to the European bilateral real exchange rates with three price and cost indexes (see the survey of MacDonald 1995). Nevertheless it may be reminded that Whitt (1992), using annual data on the post Bretton Woods period (19501989) for the real exchange rate of the French Franc against the Dollar, concludes: "the Dickey-Fuller test statistic is able to reject the unit root hypothesis at the 95 percent significance level in only one case, the French CPI results". Moreover, Cheung and al. (1995), using WPI monthly data over the period from March 1979 to December 1986, and studying bilateral relations, reveal cointegration relations between the German prices on one side, and the prices (corrected by the exchange 
rate) of France, Belgium, Italy and Netherlands on an other side. Our results go in the same direction, insofar as with WPI, we have mean-reverting processes in seven cases.

\section{Acknowledgement}

We wish to thank Jacques Le Cacheux, Jerome Stein, the editor and two anonymous referees for comments and suggestions. Any remaining errors are the sole responsibility of the authors.

Date accepted: July 2001

\section{References}

Abuaf, N. and Jorion, P. (1990), "Purchasing Power Parity in the Long Run”, The Journal of Finance, March.

Adler, M. and Lehmann, B. (1983), "Deviations from Purchasing Power Parity in the Long Run", The Journal of Finance 38; pp. 1471-1487.

Amano, R. A. and Van Norden, S. (1992), "Unit-root Tests and the Burden of Proof", Bank of Canada Working Paper ${ }^{\circ} 92-7$, Nov. 92.

Balassa, B. (1964), "The Purchasing Power Parity Doctrine: A Reappraisal", Journal of Political Economy 72, Dec.; pp. 584-96.

Banerjee, A., Lumsdaine, R.L. and Stock, J. H. (1992), "Recursive and Sequential Tests of the Unit-Root and Trend-Break Hypotheses: Theory and International Evidence", Journal of Business \& Economic Statistics 10, July, n³.

Barkoulas, J. T., and Baum C. F. (1998), "Fractional Dynamics in Japanese Financial Time Series", Pacific-Basin Finance Journal 6.

Barkoulas, J. T., Baum C. F. and CAGLAYAN, M. (1999), "A Reexamination of the Long-Memory Evidence in the Foreign Currency Market”, Boston College Working Paper.

Baum, C. F., Barkoulas, J. T. and CAGLAYAN, M. (1998), "Long Memory or Structural Breaks: Can Either Explain Nonstationarity Real Exchange Rates Under the Current Float?", Boston College Working Paper

Bleaney, M., Leybourne, S. and Mizen, P. (1999), "Mean Reversion of Real Exchange Rates in High-Inflation Countries", Southern Economic Journal 65; pp.839-854.

Box, G. E. and Jenkins, G. M. (1976), Times Series Analysis: Forecasting and Control, Holden-Day.

Breuer, J.B. (1994), “An Assessment of The Evidence on Purchasing Power Parity”, in Estimating Equilibrium Exchanges Rates, J.WILLIAMSON ed., Institute for International Economics, Washington. 
CASSEL, G. (1916), “The Present Situation of The Foreign Exchanges”, Economic journal, Sept.

Cassel, G.(1923), La monnaie et le change après 1914, Paris, Giard.

Cheung, Y. W. (1993), "Long Memory in Foreign-Exchange Rates”, Journal of Business and Economic Statistics 11; pp. 93-101.

Cheung, Y. W., Fung, H-g., Lai, K. S. and Lo, W-C. (1995), "Purchasing Power Parity under the European Monetary System", Journal of International Money and Finance 14, nº 2 ; pp. 179-189.

Christiano, L.J. (1992), "Searching for a Break in GNP”, Journal of Business \& Economic Statistics 10, July, $\mathrm{n}^{\circ} 3$.

Crouhy-veyrac, L. and Saint Marc, M. (1995), “The Natural Real Exchange Rate between the French Franc and the Deutchmark: Implications for Monetary Union", in Fundamental Determinants of Exchange Rates, J. STEIN and al. eds., Oxford

Dickey, D. A. and Fuller, W. A. (1979), "Distribution of the estimators of autoregressive time series with a unit root", Journal of the American Statistical Association 74; pp. 427-431.

Dickey, D. A. and Fuller, W. A. (1981), "Likelihood ratio tests for autoregressive time series with a unit root", Econometrica 49; pp. 1057-1072

Diebold, F.x. and Rudebusch, G.D. (1989), "Long Memory and Persistence in Aggregate Output", Journal of Monetary Economics 24; pp. 189-209.

Diebold, F., Husted, S. and Rush, M. (1991), "Real Exchange Rates under the Gold Standard", Journal of Political Economy 99, n6.

Dornbusch, R. (1989), "Real Exchange Rates and Macroeconomics: A Selective Survey", Scandinavian Journal of Economics 2; pp. 401-432.

Eichengreen, B. (1993), "The Crisis in the EMS and Transition to EMU: An Interim Assessment”, CEPR Working Paper n ${ }^{\circ}$ C93-022.

Evans, G.W. (1989), "Output and Unemployment Dynamics in the United States: 19501985", Journal of Applied Econometrics 4; pp. 217-237.

Geweke, J. and Porter-Hudak, S. (1983), "The Estimation and Application of Long Memory Time Series Models", Journal of Time Series Analysis 4; pp. 221-238.

Giavazzi, F. and Giovannini, A. (1989), Limiting Exchange Rate Flexibility: The European Monetary System, MIT Press.

Granger,c.W.J. (1980), "Long Memory Relationships and the Aggregation of Dynamic Models”, Journal of Econometrics 25; pp. 227-238.

Granger, C.W.J. and Joyeux, R. (1980), “An Introduction to Long-memory Time Series Models and Fractional Differencing”, Journal of Time Series Analysis 1; pp. 15-39.

de Grauwe, P. (1983), "Symptoms of an Overvalued Currency: the Case of the Belgium Franc", in International Economic Adjustment: Small Countries System, DE CECCO (ed.) Basic Blackwell, England.

de Grauwe, P. (1994), The Economics of Monetary Integration, Oxford University Press , 2nd edition.

de Grauwe, P. and Heens, H. (1993), "Real Exchange Rate Variability in Monetary 
Unions”, Recherches Economiques de Louvain 59, n 1-2; pp. 105-117.;

Grilli, V. and Kaminsky, G. (1991), "Nominal Exchange Rate Regimes and the Real Exchange Rate, Journal of Monetary Economics, 27; pp. 191-212.

Hakkio, C. S. (1992), "Is Purchasing Power Parity a Useful Guide to the Dollar ?", Federal Reserve Bank Of Kansas City Economic Review.

Hosking, J.R.M. (1981), "Fractional Differencing”, Biometrika 68; pp. 165-76.

Kwiatkowski, D., Phillips P. C. B., Schmidt, P. and Shin Y. (1992), "Testing the Null of stationarity against the alternative of a unit root: how sure are we that economic time series have a unit root ?", Journal of Econometrics 54; pp. 159-178.

Leybourne, S.J. and McCabe, B.P.M. (1994), “A consistent test for a unit root”, Journal of Business and Economic Review 12; pp. 157-166.

Leybourne, S.J. and Newbold, P. (1999), "The Behaviour of Dickey-Fuller and PhillipsPerron tests under the alternative hypothesis”, Econometrics Journal 2; pp.92-106.

Macdonald, R. (1985a), "Do Deviations of the Real Effective Exchange Rate Follow a Random Walk?” Economic Notes 14; pp. 63-70.

Macdonald, R. (1985b), “Are Deviations from Purchasing Power Parity Efficient: Some Further Answers", Weltwirstschaftliches Archiv 121; n 4, pp. 638-645.

Macdonald, R. (1995), "Long-Run Exchange Rate Modeling”, IMF Staff Papers 42; n³, pp. 437-489.

Meese, R.a. and Rogoff, K. (1983), "Empirical Exchange Rate Models of The Seventies, Do they fit out sample ?", Journal of International Economics 14; pp. 3-24.

Meese, R.a. and Rogoff, K. (1988), "Was it real ? The Exchange Rate-Interest Differential Relation Over the Modern Floating-Rate Period”, Journal of Finance 43; pp. 933-948.

Montanes, A. and Reyes, M. (1998), "Effect of a Shift in the Trend Function on DickeyFuller Unit Root Tests”, Econometric Theory 14; pp. 347-389.

Nelson, C.R. and Plosser, C. (1982), "Trends and random walks in macro economic time series: some evidence and implications", Journal of Monetary Economics 10; pp. 139162.

$\mathrm{Ng}, \mathrm{S}$ and Perron, P. (1995), "Unit root tests in ARMA models with data-dependent methods for the selection of the truncation lag", Journal of the American Statistical Association 90,pp. 268-281.

Officer, L.H (1976), “The Purchasing Power Parity Theory and Exchange Rates: a Review Article", International Monetary Fund Staff Papers, March.

Officer, L.H. (1982 a), Purchasing Power Parity and Exchange Rates: Theory, Evidence and Relevance, JAI Press, London.

Officer, L.H., (1982 b), "The Relationship between the Absolute and the Relative PPP Theory of Cassel", History of Political Economy.

Perron, P. (1989), "The Great Crash, the Oil Price Shock, and the Unit Root Hypothesis", Econometrica 57; n6, pp. 1361-1401.

Perron, P. (1990), “Testing for a Unit Root in a Time Series With a Changing Mean”, Journal of Business \& Economic Statistics 8, April, $\mathrm{n}^{\circ} 2$.

Perron, P. (1997), "Further Evidence on Breaking Trend Functions in Macroeconomic 
Variables", Journal of Econometrics 80; pp. 355-385.

Perron, P. and Ng, S. (1996), "Useful Modifications to Some Unit Root Tests with

Dependent Errors and Their Local Asymptotic Properties", Review of Economic Studies 63; pp. 435-463.

Phillips, P.C. (1987), "Towards a unified asymptotic theory for autoregression", Biometrika 74; pp. 535-547.

Phillips, P.C. and PERRON, P (1988), “Testing for a unit root in time series regression”, Biometrika 75; pp. 335-346.

Rappoport, P. and Reichlin, L. (1989), "Segmented Trends and Nonstationarity Time Series", Economic Journal 99; pp. 168-177.

Robinson, P.M. (1995), "Gaussian Semiparametric Estimation of Long Range Dependence", Annals of Statistics 23; pp. 1630-1661.

Roll R., (1979), "Violations of Purchasing Power Parity and their Implications for Efficient Commodity Markets", in International Finance and Trade , M. Sarnat et G. Szego (eds.), Cambridge, Mass.: Ballinger; pp. 133-176.

Said, E. S. and Dickey, D. A. (1984), “Testing for Unit Roots in Autoregressive Moving Average Models of Unknown Order", Biometrika 71; pp. 599-607.

Samuelson, P.A. (1964), "Theoretical Notes on Trade Problems", Review of Economics and Statistics 46; pp. 595-608.

Schwert, G.W. (1989), "Tests for unit root: a Monte Carlo investigation", Journal of business and Economic Statistics 7; pp. 147-159.

Stein, J. and al. eds. (1995), Fundamental Determinants of Exchange Rates, Clarendon Press, Oxford.

Thygesen, N. (1979), “The Emerging European Monetary System: Precursors, First Steps and Policy Options", in TRIFFIN (ed.) EMS-The Emerging European Monetary System, National Bank of Belgium.

Vogelsang, T.j. and Perron, P. (1998), “Additional Tests for a Unit Root Allowing for a Break in the Trend Function at an Unknown Time", International Economic Review 39; $n^{\circ} 4$, November.

Von Hagen, J. and Neumann, M. (1994), "Real Exchange Rates Within and Between Currency Areas: How Far Away in EMU ?", Review of Economics and Statistics 76; pp. 236-244.

Whitt, J. A. (1992), "The Long-Run Behavior of the Real Exchange Rate: A Reconsideration”, Journal of Money Credit and Banking 24; ${ }^{\circ} 1$.

Wypolsz, C. (1991), "On the Real exchange Rate effect of German Unification”, Weltwirtschaftliches Archiv 127; pp. 1-17.

Zivot, E. and Andrews, D.W.K., (1992), "Further Evidence on the Great Crash, the OilPrice Shock, and the Unit-Root Hypothesis", Journal of Business \& Economic Statistics 10 July, n³. 


\section{Annex 1: Realignments in the EMS}

1979: September 24: Revaluation of the Mark by 2\%. Devaluation of the Danish Krone by $2.9 \%$.

November 30: Devaluation of the Danish Krone by $4.8 \%$.

1981: March 23: Devaluation of the Lira by $6 \%$.

October 5: Revaluation of the Mark and the Dutch Guilder by $5.5 \%$. Devaluations of the French Franc and the Lira by $3 \%$.

1982: February 22: Devaluation of the Belgian Franc by $8.5 \%$. Devaluation of the Danish Krone by $3 \%$.

June 14: Revaluation of the Mark and the Dutch Guilder by $4.25 \%$.

Devaluation of the French Franc by $5.75 \%$ and of the Lira by $2.75 \%$.

1983: March 21: Revaluation of the Mark by 5.5\%, of Dutch Guilder by $3.5 \%$, of the Danish Krone by $2.5 \%$ and of the Belgian Franc by $2.5 \%$.

Devaluation of the Irish Punt by $3.5 \%$.

1985: July 22: Revaluation of the Mark, of the Dutch Guilder, of the Danish Krone, of the French Franc, of the Belgian Franc and the Irish Punt by $2 \%$.

Devaluation of the Lira by $6 \%$.

1986: April 7: Revaluation of the Mark and the Dutch Guilder by 3\%, of the Belgian Franc and the Danish Krone by $1 \%$.

Devaluation of the French Franc by $3 \%$.

August 4: Devaluation of the Irish Punt by $8 \%$.

1987: January 12: Revaluation of the Mark and the Dutch Guilder by $3 \%$.

Revaluation of the Belgian Franc by $2 \%$.

1989: June 19: Admission of the Peseta

1990: January 5: Reduction of the band for the Lira at $+/-2.25 \%$.

October 8: Admission of the Sterling Pound

1992: April 6: Admission of the Escudo

September 14: Devaluation of the Lira by 3.5\%. Revaluation of the others currencies by $3.5 \%$.

September 17: Exit of the Sterling Pound. Devaluation of the Peseta by $5 \%$. Exit of the Lira.

November 23: Devaluation of the Peseta and the Escudo by $6 \%$.

1993: January 30: Devaluation of the Irish Punt by $10 \%$.

May 13: Devaluation of the Peseta of $8 \%$ and the Escudo by $6.5 \%$. 
August 2: Widening the band at $+/-15 \%$.

1995: January 9: Admission of the Austrian Shilling.

March 6: Devaluation of the Peseta by $7 \%$ and the Escudo by $3.5 \%$.

1996: October 14: Admission of the Finnish Markka.

November 1996: Return of the Lira.

1998: March 16: Revaluation of the Irish Punt by 3\%. Admission of the Greek Drachma.

\section{Annex 2: Presentation of the Unit Root Tests}

I. The three ADF tests(Augmented Dickey Fuller) were introduced by Dickey and Fuller (1979) and generalized to $\operatorname{ARIMA}(p, 1, q)$ processes with $p$ and $q$ unknowns by Said and Dickey (1984). From the parametric regression

$$
\Delta r_{t}=\rho r_{t-1}+\sum \delta_{j} \Delta r_{t-j}+\varepsilon_{t} \text { with } \Delta r_{t}=r_{t}-r_{t-1}
$$

We know that $n(\hat{\rho}-1) \stackrel{\text { law }}{\rightarrow} \frac{\int_{0}^{j=1} W(s) d W(s)}{\left(\int_{0}^{1} W^{2}(s) d s\right)} W$ being a standard Brownian motion in
C $[0,1]$.

The test statistic ADF1 is the t-statistic associated to the least square estimation of the coefficient $\rho$ (the ratio of $(\hat{\rho}-1)$ and its standard deviation). Null hypothesis is nonstationarity $\mathrm{H}_{0}: \rho=0$ against the alternative of stationarity $\rho<1$, the statistic $t_{\hat{\rho}}$ follows under $\mathrm{H}_{0}$ a law which is not a standard Student distribution but $t_{\hat{p}} \stackrel{\text { law }}{\rightarrow} \frac{\int_{0}^{1} W(s) d W(s)}{\left(\int_{0}^{1} W^{2}(s) d s\right)^{1 / 2}}$. This law was tabulated by Fuller (1976) and critical values are $-1.95(5 \%)$ and $-1.61(10 \%)$.

Test ADF2 allows testing nonstationarity against the stationarity in level from the regression $\Delta r_{t}=\mu+\rho r_{t-1}+\sum_{j=1}^{k} \delta_{j} \Delta r_{t-j}+\varepsilon_{t}$, critical values are in that case -2.9 $(5 \%)$ and $-2.59(10 \%)$.

Test ADF3 is the most general because built on the regression $\Delta r_{t}=\mu+\beta t+\rho r_{t-1}+\sum^{k} \delta_{j} \Delta r_{t-j}+\varepsilon_{t}$ it allows testing $\mathrm{H}_{0}: \rho=0$ against the alternative of trend stationarity. The statistic is always the $t$ ratio statistic $t_{\hat{\rho}}$ associated to the estimate of $\rho$ and critical values are $-3.45(5 \%)$ and $-3.15(10 \%)$.

II. Semiparametric tests by Phillips and Phillips Perron (PP) are constructed to test nonstationarity against the simple stationarity (Phillips), level-stationarity (with a constant) (PP1) or trend-stationarity (PP2) from models $r_{t}=\rho r_{t-1}+u_{t}, r_{t}=$ 
$\mu+\rho r_{t-1}+u_{t}$ or $r_{t}=\left(\mu+\beta t+\rho r_{t-1}+u_{t}\right)$, or with $u_{t}$ a stationary process. In that case ADF statistics presents two nuisance parameters because $n(\hat{\rho}-1)$

$$
\stackrel{\operatorname{law}}{\rightarrow} \frac{\int_{0}^{1} W(s) d W(s)+\lambda}{\left(\int_{0}^{1} W^{2}(s) d s\right)} \text { and }{ }_{\hat{p}} \stackrel{\operatorname{law}}{\rightarrow} \omega \frac{\int_{0}^{1} W(s) d W(s)+\lambda}{\left(\int_{0}^{1} W^{2}(s) d s\right)^{1 / 2}} \text {. These parameters are estimated by }
$$

nonparametrics methods (a Newey-West estimation of $u_{t}$ s variance). One can so build two statistics $Z_{\rho}=n(\hat{\rho}-1)-\hat{\lambda} /\left(n^{-2} \sum r_{t}^{2}\right)$ which critical values under $H_{0}$ are-8 $(5 \%)$ and-5.7 $(10 \%)$ and $Z_{i}=\frac{\sigma_{u}}{\hat{\omega}} t_{\hat{p}}-\hat{\lambda} / \hat{\omega}\left(n^{-2} \Sigma r_{t}^{2}\right)^{1 / 2}$ which distribution is the same that for ADF1.

For PP1 and PP2, statistics $Z_{\rho}$ have for critical values:-14 (5\%) and-11.2 (10 $\%)$ in the case of the alternative of level stationarity and-21.5 (5\%) and-18.1 (10 $\%$ ) for the trend-stationarity.

III. The Kwiatkowski-Phillips-Schmidt-Shin (KPSS) test is a test of stationarity (null hypothesis is the stationarity in level for KPSS1 and in tendency for KPSS2). The sequence of observations is decomposed as the sum three components (a determinist trend, a random walk and a stationary error term): $r_{t}=\beta t+y_{t}+\varepsilon_{t}$ with $y_{t}=y_{t-1}+u_{t}$ where $\varepsilon_{t}$ is a stationary noise, $\left(u_{t}\right)$ a sequence of random variables independent and identically distributed $\left(0, \sigma_{u}^{2}\right)$. The initial value of the random walk $y$ is denoted by $y_{0}$. The hypothesis of stationarity is $H_{0}: \sigma_{u}^{2}=0$. In case where $\beta=0$, the stationarity is around $y_{0}$ while when the opposite occur it is a trend stationarity around $t+y_{0}$. The test is based on the Lagrange Multiplier (LM) statistic: the estimated error $\hat{e}_{t_{n}}=r_{t}-\ddot{\mu}$ or $\hat{e}_{t_{n}}=r_{t}-\ddot{\mu}-\ddot{\beta} t$ is calculated, an estimation of the variance is $s^{2}(k)=\frac{1}{n} \sum_{t=1}^{n} \hat{e}_{t}^{2}+\frac{2}{n} \sum_{j=1}^{k} \omega(j, k) \sum_{t=j+1}^{n} \hat{e}_{t} \hat{e}_{t-j}$ where $\omega(j, k)$ are the weights dependent on the choice of the window of the spectrum (for KPSS $\sum_{n} \mathrm{we}_{t}$ use Bartlett's window for which $\left.\omega(j, k)=1-\frac{j}{k+1}\right)$. The test statistic is $\hat{\eta}=\frac{\sum_{t=1}\left(\sum_{i=1} \hat{e}_{i}\right)^{2}}{n^{2} s^{2}(k)}$ and it is calculated for various delay $k$. The law of this statistics is tabulated in KPSS (1992) and critical values are $0.463(5 \%)$ and $0.347(10 \%)$ for KPSS1 and $0.146(5 \%)$ and $0.119(10 \%)$ for KPSS2.

\section{Annex 3: Box-Jenkin's Method}

The estimates of the different parameters of an ARIMA $(p, d, q)$ process are obtained by the Conditional Least Squares method: these estimations are calculated under the hypothesis that non-observed errors in past are null. The series can be represented in terms of observations of his past $r_{t}=\varepsilon_{t}+\sum_{i=1}^{\infty} \pi_{i} r_{t-i}$ and weights 
are calculated from the ratio of polynomials $\Phi$ and $\Theta: \frac{\Phi(B)}{\Theta(B)}=1-\sum_{i=0}^{\infty} \pi_{i} B^{i}$. Estimations are obtained by minimizing the quantity $\sum_{t=1}^{n} \hat{\varepsilon}_{t}^{2}=\sum_{t=1}^{n}\left(r_{t}-\sum_{i=1}^{\infty} \hat{\pi}_{t} r_{t-i}\right)^{2} \quad$ where the non-observed past values of $r_{t}$ are fixed to 0 and the $\hat{\pi}_{i} \Phi$ are calculated in every iteration. The Maximum Likelihood method was also applied: the logarithm of the likelihood is $-\frac{1}{2} r^{\prime} \Omega^{-1} r-\frac{1}{2} \ln (|\Omega|)-\frac{n}{2} \ln \left(\sigma^{2}\right) \quad$ with $r^{\prime}=\left(r_{1}, r_{2}, \ldots, r_{n}\right)$ et $\sigma^{2} \Omega$ the variance matrix of $r$. The Maximum Likelihood estimator of is and the estimations of parameters are obtained by minimizing $(|\Omega|)^{1 / n} r^{\prime} \Omega^{-1} r$. In theory, second method is more accurate but the results that we obtained by these two ways are very close.

In case where several models are possible, we choose the model that presents the smallest quantity of information. The estimations of the quantity of information that were proposed are:

$$
\begin{aligned}
& \operatorname{AIC}(p, q)=\ln \left(\hat{\sigma}^{2}\right)+\frac{2}{n}(p+q), \text { Aka ïke } 1969 \\
& B I C(p, q)=\ln \left(\hat{\sigma}^{2}\right)+\frac{\ln (n)}{n}(p+q), \text { Aka ïke } 1969 \\
& H Q(p, q)=\ln \left(\hat{\sigma}^{2}\right)+c \frac{\ln \ln n}{n}(p+q), c>2, \text { Hannan Quinn } 1979
\end{aligned}
$$

where $\hat{\sigma}^{2}$ is the MLE of $\sigma^{2}$. We used the first criterion (AIC). A standard approach for diagnostic checking aim to examine if the residual series obtained is coherent with the hypothesis according to which it forms a white noise. We used the Ljung-Box test (1978) or the Modified Portmanteau test: under the hypothesis of white noise, the statistic $Q_{k}^{*}=n(n+2) \sum_{i=1}^{k} \frac{\gamma_{i}^{2}}{n-k}$, with $\gamma_{i}=\frac{\sum_{i=k+1}^{n} \hat{\varepsilon}_{t} \hat{\varepsilon}_{t-k}}{\sum_{i=k+1}^{n} \hat{\varepsilon}_{t}^{2}}$ follows a chi squared distribution with $k-p-q$ degrees of freedom.

\section{Annex 4: Perron's Tests with Determination of the Break Point}

We consider three models. In each model the unit-root test is performed using the t-statistic for testing $\alpha=1$.

In the Model 1, we allow a change in the intercept at time break (TB), in the following regression:

$$
y_{t}=\mu+\theta \cdot D U_{t}+\beta \cdot t+\delta \cdot D T B_{t}+\alpha \cdot y_{t-1}+\sum_{i=1}^{k} c_{i} \cdot \Delta y_{t-i}+e_{t}
$$


Table A4.1. Estimation of the model 1

\begin{tabular}{|ccccccccccc|}
\hline Series & Time Break $k$ & $\hat{\beta}$ & $t_{\beta}$ & $\hat{\theta}$ & \multicolumn{1}{c}{$t_{\beta}$} & $\hat{\delta}$ & \multicolumn{1}{c}{$t_{\delta}$} & $\hat{\alpha}$ & $t_{\alpha}$ \\
\hline French Franc: & $1993: 02$ & 3 & 0.0002 & 1.61 & -0.0247 & -2.59 & 0.0179 & 0.81 & 0.66 & $-4.98^{*}$ \\
CPI & & & & & & & & & & \\
WPI & $1982: 04$ & 9 & -0.0006 & -3.44 & 0.0209 & 2.86 & -0.0314 & -1.55 & 0.75 & -3.85 \\
ULC & $1987: 02$ & 4 & 0.00005 & 0.07 & -0.0784 & -3.76 & 0.0562 & 1.70 & 0.46 & $-5.67^{* *}$ \\
Dutch Guilder: & $1988: 03$ & 8 & -0.0002 & -2.09 & -0.0107 & -2.57 & 0.0097 & 1.08 & 0.69 & -4.29 \\
CPI & $1978: 04$ & 0 & 0.0001 & 2.53 & -0.0219 & -4.51 & 0.0157 & 1.42 & 0.51 & $-5.97^{* *}$ \\
WPI & $1993: 02$ & 4 & -0.0015 & -2.20 & 0.0362 & 2.69 & -0.0281 & -0.93 & 0.81 & -2.18 \\
ULC & $1993: 02$ & & & & & & & & & \\
Belgian Franc: & $1981: 02$ & 3 & 0.00006 & 0.72 & -0.0259 & -4.27 & 0.0400 & 2.76 & 0.74 & $-6.31^{* *}$ \\
CPI & & & & & & & & & & \\
WPI & $1981: 02$ & 1 & -0.0004 & -3.42 & -0.0552 & -5.74 & 0.0484 & 3.16 & 0.70 & $-5.88^{* *}$ \\
ULC & $1993: 02$ & 4 & -0.0020 & -3.82 & 0.0677 & 3.74 & -0.0867 & -2.15 & 0.79 & -3.86 \\
Italian Lira: CPI & $1992: 01$ & 8 & 0.0019 & 4.84 & -0.1182 & -5.01 & 0.1037 & 2.46 & 0.68 & $-5.31^{* *}$ \\
WPI & $1992: 01$ & 8 & 0.0013 & 4.32 & -0.0844 & -4.50 & 0.0930 & 2.27 & 0.48 & $-5.39^{* *}$ \\
ULC & $1992: 01$ & 8 & 0.0004 & 1.25 & -0.0824 & -3.34 & 0.0860 & 1.52 & 0.69 & -4.17 \\
Spanish Peseta: & $1992: 03$ & 9 & 0.0011 & 2.75 & -0.0603 & -3.04 & 0.0618 & 1.44 & 0.76 & -3.31 \\
CPI & $1992: 03$ & & & & & & & & & \\
WPI & $1992: 01$ & 9 & 0.0005 & 2.12 & -0.0691 & -3.87 & 0.0688 & 1.74 & 0.65 & -4.01 \\
ULC & $1992: 01$ & 7 & 0.0011 & 2.73 & -0.0656 & -2.95 & 0.1174 & 2.01 & 0.71 & -4.04 \\
Port. Escudo: & $1976: 03$ & 4 & 0.0010 & 4.16 & -0.0520 & -2.98 & 0.0876 & 2.45 & 0.70 & $-5.27^{* *}$ \\
CPI & & & & & & & & & & \\
Austr. Shilling: & $1991: 02$ & 1 & 0.0005 & 3.39 & -0.0149 & -3.22 & 0.0115 & 1.22 & 0.80 & -4.62 \\
CPI & & & & & & & & & \\
WPI & $1979: 03$ & 7 & -0.0007 & -5.17 & 0.0187 & 3.86 & -0.0213 & -2.27 & 0.61 & $-5.05^{*}$ \\
ULC & $1982: 02$ & 6 & -0.0010 & -3.50 & 0.0102 & 0.90 & -0.0498 & -1.67 & 0.62 & -4.35 \\
\hline
\end{tabular}

Table A4.2. Estimation of the model 1 (continued)

\begin{tabular}{|cccrrrrrrrr|}
\hline \multirow{2}{*}{ Series } & $\begin{array}{c}\text { Time } \\
\text { Break }\end{array}$ & \multirow{2}{*}{$\hat{\beta}$} & $\hat{\beta}$ & \multicolumn{1}{c}{$t_{\beta}$} & $\hat{\theta}$ & \multicolumn{1}{c}{$t_{\beta}$} & $\hat{\delta}$ & $t_{\delta}$ & $\hat{\alpha}$ & $t_{\alpha}$ \\
\hline Fin. Markka: CPI & $1991: 02$ & 5 & 0.0013 & 4.62 & -0.1145 & -5.45 & 0.0747 & 1.82 & 0.70 & $-6.03^{* *}$ \\
WPI & $1991: 02$ & 5 & 0.0005 & 2.16 & -0.0905 & -4.73 & 0.0418 & 1.11 & 0.69 & $-5.69^{* *}$ \\
ULC & $1991: 02$ & 4 & -0.0008 & -2.23 & -0.1151 & -4.56 & 0.1148 & 1.87 & 0.67 & $-6.54^{* *}$ \\
Irish Punt: CPI & $1979: 04$ & 0 & -0.0005 & -2.37 & 0.0696 & 3.53 & -0.0197 & -0.57 & 0.81 & -3.70 \\
WPI & $1979: 02$ & 0 & -0.0004 & -2.12 & 0.0447 & 2.82 & -0.0284 & -0.91 & 0.73 & -3.88 \\
ULC & $1978: 03$ & 9 & -0.0036 & -4.12 & 0.0822 & 3.42 & -0.1449 & -2.74 & 0.75 & -3.80 \\
Gr. Drachma: CPI & $1985: 01$ & 8 & 0.0017 & 4.76 & -0.0777 & -4.43 & 0.0492 & 1.36 & 0.45 & $-5.57^{* *}$ \\
WPI & $1985: 01$ & 3 & 0.0009 & 3.89 & -0.0678 & -4.45 & 0.0701 & 2.15 & 0.65 & $-5.08^{*}$ \\
ULC & $1985: 02$ & 7 & 0.0021 & 3.26 & -0.1250 & -3.60 & 0.0828 & 1.14 & 0.77 & -3.77 \\
Swedish Krone: & & & & & & & & & & \\
CPI & $1992: 02$ & 5 & 0.00006 & 0.26 & -0.0683 & -3.71 & 0.0603 & 1.33 & 0.61 & $-5.21^{* *}$ \\
WPI & $1992: 02$ & 9 & -0.0002 & -0.99 & -0.0867 & -4.22 & 0.0446 & 1.07 & 0.30 & $-5.35^{* *}$ \\
ULC & $1992: 01$ & 4 & -0.0022 & -4.09 & -0.0699 & -2.81 & 0.1375 & 2.17 & 0.63 & $-5.21^{* *}$ \\
Danish Krone: CPI & $1990: 04$ & 8 & 0.0004 & 3.44 & -0.0215 & -3.26 & 0.0447 & 2.79 & 0.78 & -3.77 \\
WPI & $1978: 03$ & 4 & 0.0001 & 1.46 & -0.0196 & -2.88 & 0.0107 & 0.68 & 0.67 & -4.22 \\
\hline
\end{tabular}


Table A4.2. (continued)

\begin{tabular}{|ccccccccccc|}
\hline Series & $\begin{array}{c}\text { Time } \\
\text { Break }\end{array}$ & $k$ & $\hat{\beta}$ & $t_{\beta}$ & $\hat{\theta}$ & $t_{\beta}$ & $\hat{\delta}$ & $t_{\delta}$ & $\hat{\alpha}$ & $t_{\alpha}$ \\
\hline Sterling Pound: & & & & & & & & & & \\
CPI & $1978: 03$ & $9-0.0005$ & -1.71 & 0.0761 & 3.09 & -0.1215 & -2.27 & 0.78 & -3.62 \\
WPI & $1978: 03$ & $9-0.0002$ & -0.72 & 0.0747 & 2.93 & -0.1067 & -2.05 & 0.74 & -3.43 \\
ULC & $1978: 03$ & $6-0.0006$ & -1.52 & 0.0505 & 1.79 & -0.0705 & -1.08 & 0.80 & -2.98 \\
\hline
\end{tabular}

$* *$ and $*$ indicate significance at 5 percent and 10 percent.

Table A4.3. Estimation of the model 2

\begin{tabular}{|c|c|c|c|c|c|c|c|c|c|}
\hline Series & $\begin{array}{c}\text { Time } \\
\text { Break }\end{array} k$ & $\beta$ & $t_{\beta}$ & $\theta$ & $t_{\beta}$ & $\gamma$ & $t_{\gamma}$ & $t_{\delta}$ & $\hat{\alpha}$ \\
\hline \multicolumn{10}{|c|}{ French Franc: } \\
\hline & 1992: 023 & 0.0002 & 2.00 & -0.0127 & -0.19 & -0.0002 & -0.23 & 0.01010 .43 & $0.65-5.24 *$ \\
\hline WPI & 1982: 049 & -0.0012 & -2.29 & 0.0049 & 0.32 & 0.00006 & 1.19 & $-0.0325-1.61$ & $10.70-3$. \\
\hline ULC & 1987: 024 & -0.0001 & -0.39 & -0.0995 & -2.81 & 0.0004 & 0.73 & 0.05941 .78 & $0.47-5.41^{*}$ \\
\hline \multicolumn{10}{|c|}{ Dutch Guilder: } \\
\hline & 1991: 028 & -0.0003 & -3.39 & -0.0643 & -2.90 & 0.0007 & 2.57 & 0.01121 .22 & $0.68-4.43$ \\
\hline WPI & 1978: 040 & 0.0012 & 3.70 & -0.0102 & -1.74 & $-0.0011-$ & -3.33 & 0.01901 .81 & $0.40-7.08 *$ \\
\hline ULC & 1990: 018 & -0.0049 & -4.05 & -0.3 & -4.08 & 0.0046 & 4.31 & 0.04111 .42 & $0.42-3.98$ \\
\hline \multicolumn{10}{|c|}{ Belgian Franc: } \\
\hline & 1981: 029 & 0.0008 & 1.58 & -0.0128 & -0.94 & -0.0009 & -1.59 & $-0.0128-0.94$ & $0.56-5.66^{*}$ \\
\hline WPI & 1981: 032 & -0.0016 & -5.54 & -0.0989 & -7.10 & & 4.21 & 0.01821 .20 & $0.61-6.86^{*}$ \\
\hline ULC & 1989: 024 & -0.0 & -5 & & & 0.0051 & 4.66 & & \\
\hline \multicolumn{10}{|c|}{ Italian Lira: } \\
\hline CPI & 1988: 028 & 0.0017 & 2.99 & 0.2687 & 2.81 & -0.0040 & -2.99 & $-0.0218-0.50$ & $0.71-3.65$ \\
\hline WPI & 1992: 010 & 0.0010 & 3.59 & -0.3716 & -3.33 & 0.0034 & 2.73 & 0.11432 .57 & $0.61-5.55^{*}$ \\
\hline ULC & 1989: 039 & 0.0010 & 2.04 & 0.2380 & 2.04 & -0.0038 & -2.38 & $-0.0723-1.29$ & $0.61-3.8$ \\
\hline \multicolumn{10}{|c|}{ Spanish Peseta: } \\
\hline$T$ & 1989: 049 & 0.0013 & 2.74 & 0.3382 & 2.80 & & & & $0.64-3.37$ \\
\hline WPI & 1989: 038 & 0.0004 & 1.53 & 0.3271 & 3.29 & -0.0044 & -3.48 & $-0.0457-1.11$ & $0.48-4$ \\
\hline ULC & 1977: 040 & 0.0027 & 1.01 & 0.0879 & 2.04 & -0.0029 & -1.05 & $-0.1224-1.93$ & $0.77-3.74$ \\
\hline \multicolumn{9}{|l|}{ Port. Escuds } & $0.69-5.18$ \\
\hline \multicolumn{10}{|c|}{ Austr. Shilling: } \\
\hline CPI & 1985: 0 & 0.0011 & 5.00 & 0.0771 & 5.33 & -0.0012 & $-5.03-$ & $-0.0107-1.24$ & $0.56-6.48$ \\
\hline WPI & 1979: 035 & 0.0003 & 0.72 & 0.0428 & 3.79 & -0.0010 & -2.26 & 0.04293 .79 & $0.55-5.94$ \\
\hline ULC & 1982: 036 & -0.0022 & -3.73 & -0.0240 & -1.18 & 0.0013 & 2.29 & $-0.0204-0.69$ & $0.62-4.51$ \\
\hline
\end{tabular}


Table A4.4. Estimation of the model 2 (continued)

\begin{tabular}{|c|c|c|c|c|c|c|c|c|c|c|c|c|}
\hline Series & $\begin{array}{l}\text { Time } \\
\text { Break }\end{array}$ & $k$ & $\beta$ & $t_{\beta}$ & $\theta$ & $t_{\beta}$ & $\hat{\gamma}$ & $t_{\gamma}$ & $\delta$ & $t_{\delta}$ & $\alpha$ & $t_{\alpha}$ \\
\hline $\begin{array}{c}\text { Fin. Markka: } \\
\text { CPI }\end{array}$ & 1991: 02 & 5 & 0.0018 & 4.99 & 0.1003 & 0.94 & -0.0027 & -2.06 & 0.0651 & 1.60 & 0.62 & \\
\hline WPI & 1991: 02 & 5 & 0.0005 & 2.19 & -0.0452 & -0.50 & -0.0005 & -0.51 & 0.0372 & .96 & 0.68 & -5.4 \\
\hline ULC & 1992: 01 & 4 & $-0.0011-$ & & & -1.65 & & 0.97 & 0.1005 & .50 & 0.61 & \\
\hline $\begin{array}{l}\text { Irish Punt: } \\
\text { CPI }\end{array}$ & 1983: 01 & 6 & $0.0022-$ & -3.37 & 56 & 3.89 & -0.0 & -3.76 & -0.0 & 0.0518 & 0.76 & -4.15 \\
\hline WPI & 1985: 03 & 0 & 0.0018 & 4.53 & 0.0858 & 2.81 & -0.1 & -3.96 & 0.0115 & 39 & 0.65 & -5.10 \\
\hline ULC & 1985: 03 & 10 & -0.0 & -0.16 & 0.2453 & 2.79 & -0.1 & -3 & & 48 & 0.52 & -4.00 \\
\hline $\begin{array}{l}\text { Gr. Drachma: } \\
\text { CPI }\end{array}$ & 1985: 01 & 8 & & 3.62 & & -2 & -0.0 & & & .28 & 0.45 & \\
\hline WPI & 1985: 01 & 3 & 0.0011 & 2.92 & -0.0568 & -2.17 & -0.0002 & -0.51 & 0.0679 & .06 & 0.65 & -5.09 \\
\hline ULC & 1985: 02 & 9 & 0.0078 & 4.43 & 0.1976 & 2.05 & -0.00 & -3.49 & 0.1101 & .58 & 0.39 & -5.18 \\
\hline $\begin{array}{c}\text { Swedish Kror } \\
\text { CPI }\end{array}$ & 1994: 01 & 5 & -0.0 & -1 & & & & 1.47 & & 0.46 & 0.55 & \\
\hline WPI & 1992: 02 & 5 & -0.0002 & -1.06 & -0.40 & -3.32 & 0.0038 & 2.88 & & .58 & 0.55 & $-5.43^{*}$ \\
\hline ULC & 1992: 01 & 4 & -0.0022 & -4.19 & $-0.4941-$ & -2.72 & 0.0048 & 2.35 & 0.1866 & 2.86 & 0.65 & -5.05 \\
\hline $\begin{array}{c}\text { Danish Kro } \\
\text { CPI }\end{array}$ & 1987: 02 & 8 & 0.0004 & 2.18 & 0.0736 & 2.67 & -0.0009 & -2.64 & & -0.63 & 0.69 & -3.45 \\
\hline WPI & 1982: 03 & 4 & $-0.0010-$ & -3.18 & $-0.0271-$ & -2.38 & 0.0010 & 3.09 & 0.0128 & 0.80 & 0.71 & -4.18 \\
\hline $\begin{array}{l}\text { Sterling Pound: } \\
\text { CPI }\end{array}$ & 1978: 03 & 9 & & 0.17 & & 1.42 & -0.0 & -0 & & 27 & .78 & -3.60 \\
\hline WPI & 1978: 03 & 9 & 0.0010 & 0.28 & 0.0954 & 1.43 & -0.0012 & -0. & & -2.06 & 0.74 & -3.42 \\
\hline ULC & 1978: 03 & 6 & $-0.0005-$ & -0.16 & 0.0515 & 0.88 & -0.00006 & -0.01 & -0.0705 & -1.07 & 0.80 & -2.96 \\
\hline
\end{tabular}

$* *$ and $*$ indicate significance at 5 percent and 10 percent.

Table A4.5. Estimation of the model 3

\begin{tabular}{|cccrrrrrl|}
\hline Series & Time & \multirow{2}{*}{\begin{tabular}{c}
\multirow{\beta}{*}{ Break } \\
\end{tabular}} & \multicolumn{1}{c}{$\hat{\beta}$} & \multicolumn{1}{c}{$\hat{\gamma}$} & $t_{\gamma}$ & $\hat{\alpha}$ & $t_{\alpha}$ \\
\hline French Franc: CPI & $1987: 02$ & 3 & 0.0014 & 5.49 & -0.0034 & -6.40 & 0.65 & $-5.25^{* *}$ \\
WPI & $1990: 01$ & 9 & -0.0017 & -6.74 & -0.0005 & -0.69 & 0.83 & -2.68 \\
ULC & $1994: 02$ & 5 & -0.0023 & -8.55 & 0.0055 & 2.38 & 0.78 & -3.29 \\
Dutch Guilder: CPI & $1979: 02$ & 9 & 0.0047 & 15.69 & -0.0061 & -17.53 & 0.60 & -4.30 \\
WPI & $1984: 01$ & 9 & -0.0010 & -7.97 & 0.0013 & 6.47 & 0.42 & $-4.71^{*}$ \\
ULC & $1990: 04$ & 8 & -0.0075 & -39.37 & 0.0071 & 10.46 & 0.52 & -3.68 \\
Belgian Franc: CPI & $1973: 02$ & 3 & 0.0514 & 1.12 & -0.0521 & -1.14 & 0.84 & 4.14 \\
WPI & $1985: 04$ & 1 & -0.0065 & -23.67 & 0.0052 & 10.36 & 0.83 & -3.97 \\
ULC & $1988: 03$ & 4 & -0.0105 & -27.06 & 1.0120 & 12.32 & 0.64 & $-5.12^{* *}$ \\
Italian Lira: CPI & $1988: 04$ & 8 & 0.0053 & 11.49 & -0.0121 & -10.14 & 0.73 & -3.48 \\
WPI & $1988: 04$ & 8 & 0.0019 & 5.13 & -0.0044 & -4.54 & 0.61 & -3.82 \\
ULC & $1986: 03$ & 9 & 0.0024 & 3.96 & -0.0093 & -7.66 & 0.58 & -4.24 \\
Spanish Peseta: CPI & $1993: 01$ & 9 & 0.0039 & 11.63 & -0.0154 & -7.65 & 0.76 & -2.80 \\
WPI & $1989: 03$ & 9 & 0.0011 & 3.26 & -0.0072 & -7.15 & 0.64 & -3.16 \\
ULC & $1979: 04$ & 0 & 0.0137 & -7.26 & -0.0137 & -7.26 & 0.78 & -3.49 \\
Port. Escudo: CPI & $1980: 04$ & 4 & -0.0033 & -3.18 & 0.0067 & 5.18 & 0.73 & $-4.93 * *$ \\
Austr. Shilling: CPI & $1989: 03$ & 4 & 0.0031 & 31.99 & -0.0041 & -14.64 & 0.64 & $-5.09 * *$ \\
WPI & $1979: 03$ & 5 & 0.0032 & 10.54 & -0.0047 & -13.13 & 0.60 & $-5.30^{* *}$ \\
ULC & $1973: 03$ & 6 & 0.0296 & 1.40 & -0.0314 & -1.47 & 0.65 & -4.08 \\
\hline
\end{tabular}


Table A4.6. Estimation of the model 3 (continued)

\begin{tabular}{|lccrrrrrc|}
\hline \multicolumn{1}{c}{ Series } & Time & \multirow{2}{*}{$\begin{array}{c}\text { Break } \\
\end{array}$} & \multicolumn{1}{c}{$\hat{\beta}$} & \multicolumn{1}{c}{$t_{\beta}$} & $\hat{\gamma}$ & \multicolumn{1}{c}{$t_{\gamma}$} & $\hat{\alpha}$ & $t_{\alpha}$ \\
\hline Fin. Markka: CPI & $1988: 04$ & 5 & 0.0050 & 10.17 & -0.0153 & -11.90 & 0.71 & $-5.01^{* *}$ \\
WPI & $1987: 02$ & 5 & 0.0022 & 3.79 & -0.0101 & -8.23 & 0.74 & $-4.85^{* *}$ \\
ULC & $1988: 01$ & 4 & -0.0022 & -2.68 & -0.0110 & -5.63 & 0.73 & $-5.35^{* *}$ \\
Irish Punt: CPI & $1985: 03$ & 6 & 0.0083 & 17.15 & -0.0122 & -14.12 & 0.78 & -3.81 \\
WPI & $1983: 02$ & 3 & 0.0045 & 10.95 & -0.0068 & -11.19 & 0.65 & -4.16 \\
ULC & $1982: 03$ & 10 & -0.0010 & -1.34 & -0.0134 & -12.20 & 0.65 & -3.14 \\
Gr. Drachma: CPI & $1994: 03$ & 0 & 0.0004 & 1.56 & 0.0082 & 3.29 & 0.71 & -4.04 \\
WPI & $1994: 01$ & 0 & 0.0007 & -2.47 & 0.0058 & 2.67 & 0.75 & -3.83 \\
ULC & $1981: 04$ & 9 & 0.0135 & 10.37 & -0.0154 & -8.85 & 0.61 & -3.68 \\
Swedish Krone: CPI & $1990: 03$ & 5 & -0.0001 & -0.30 & -0.0069 & -5.09 & 0.68 & -4.21 \\
WPI & $1987: 01$ & 5 & -0.0002 & -0.39 & -0.0033 & -3.37 & 0.70 & -3.99 \\
ULC & $1974: 02$ & 4 & 0.0203 & 1.21 & -0.0284 & -1.68 & 0.74 & -4.15 \\
Danish Krone: CPI & $1993: 02$ & 8 & 0.0015 & 9.64 & -0.0049 & -5.03 & 0.81 & -2.96 \\
WPI & $1981: 02$ & 2 & -0.0017 & -4.77 & 0.0019 & 4.36 & 0.77 & -3.66 \\
Sterling Pound: CPI & $1982: 03$ & 9 & 0.0109 & 10.41 & -0.0137 & -9.31 & 0.75 & -2.73 \\
WPI & $1981: 04$ & 9 & 0.0111 & 11.28 & -0.0119 & -9.06 & 0.74 & -2.26 \\
ULC & $1982: 04$ & 6 & 0.0061 & 4.60 & -0.0106 & -5.57 & 0.80 & -2.72 \\
\hline
\end{tabular}

** and $*$ indicate significance at 5 percent and 10 percent.

where $\mu$ is a constant, $t$ denotes the time trend and $e$ is an error process ( $e_{t}$ is i.i.d. $\left(0, \sigma^{2}\right)$; see Perron for more details);

with $D U=1$ if $t>T B$, and 0 otherwise; $D T B=1$ if $t=T B+1$, and 0 otherwise

In the Model 2, we allow both a change in the intercept and the slope at TB.

$$
y_{t}=\mu+\theta \cdot D U_{t}+\beta \cdot t+\gamma \cdot D T_{t}+\delta \cdot D T B_{t}+\alpha \cdot y_{t-1}+\sum_{i=1}^{k} c_{i} \cdot \Delta y_{t-i}+e_{t}
$$

with $D T=1 . t$ if $t>T B$, and 0 otherwise.

In the Model 3, we allow a change in the slope but both segments of the trend function are joined at TB. In a first step, the series is detrended using a regression:

$$
y_{t}=\mu+\beta \cdot t+\gamma \cdot D T_{t}^{*}+\tilde{y}_{t}
$$

with $D T^{*}=1 .(t-T B)$ if $t>T B$, and 0 otherwise. In the second step, the test is performed in the regression:

$$
\tilde{y}_{t}=\alpha \cdot \tilde{y}_{t-1}+\sum_{t=1}^{k} c_{i} \cdot \Delta \tilde{y}_{t-i}+e_{t}
$$


TB is selected as the value which minimize the $t$-statistics for testing $\alpha=1$, and the procedure selects the value of $k$, say $k^{*}$, such that the coefficient on the last lag in the regression is significant and the last coefficient in a regression of order greater than $k^{*}$ is not significant, up to a maximum order $k_{\max }$ (here $k_{\max }=10$; see Perron 1997 p.358). 